\title{
The Ngorongoro Crater as the biggest geotouristic attraction of the Gregory Rift (Northern Tanzania, Africa) - geological heritage
}

\author{
Krater Ngorongoro największą atrakcją geoturystyczną ryftu Gregory’ego \\ (północna Tanzania, Afryka) - dziedzictwo geologiczne \\ Jerzy Żaba ${ }^{1}$, Krzysztof Gaidzik ${ }^{2}$ \\ ${ }^{1,2}$ University of Silesia, Faculty of Earth Sciences, Department of Fundamental Geology, \\ ul. Będzińska 60,41-200 Sosnowiec; \\ e-mail:1jerzy.zaba@us.edu.pl,k.gaidzik@gmail.com
}
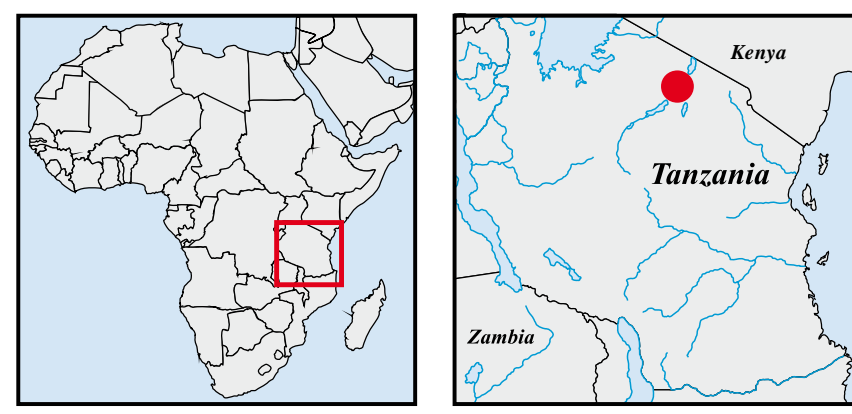

Abstract: The Ngorongoro Crater is the largest unflooded and not destroyed collapse volcanic caldera of the shield volcano on Earth. It attracts many visitors each year not only because of the undoubted wealth of the wildlife and breathtaking views, but also due to the geotouristic attractiveness of this definite location. The Crater is in fact a specific example of geological processes, relevant to the development of planet Earth. In a relatively small area one can observe rocks of different types and ages: Precambrian igneous and metamorphic rocks, volcanic rocks formed in the Pliocene, Pleistocene, and even nowadays, as well as sedimentary rocks, up to those currently forming within the caldera floor. The origin and development of the Ngorongoro volcano, and lately caldera, is closely related to the activity of rifting processes occurring along the Gregory Rift, belonging to the East African Rift System. It represents one of the three arms of the Afar triple junction associated with the located here hotspot. Due to the geotouristic attractiveness, as well as a richness of living nature and archaeological sites with discoveries of our ancestors, which illustrate an important stage in the history of mankind, the area of the Ngorongoro Crater was designated a UNESCO World Cultural and Natural Heritage Site.

Keywords: volcanoes, Ngorongoro, Tanzania, Africa, Gregory Rift, East African Rift System, geotouristc (geological) attractions

Treść: Krater Ngorongoro to największa tak dobrze zachowana (niezalana woda i niezniszczona) kaldera zapadliskowa wygastego wulkanu tarczowego na Ziemi. Przyciaga ona każdego roku nieprzebrane rzesze turystów nie tylko ze względu na zapierajace dech $w$ piersiach widoki oraz niewatpliwe bogactwo flory, a w szczególności fauny, lecz również z uwagi na swa wyjątkowa atrakcyjność geoturystyczna. Krater ten stanowi bowiem szczególny przyklad wyjątkowo istotnych dla rozwoju Ziemi procesów geologicznych. Na stosunkowo niewielkiej powierzchni można obserwować bardzo różnorodne skaty: magmowe i metamorficzne wieku prekambryjskiego, wulkaniczne powstate $w$ pliocenie, plejstocenie $i w$ czasach współczesnych, a także różnowiekowe utwory osadowe. Powstanie i rozwój wulkanu, a następnie kaldery Ngorongoro jest ściśle związany z aktywnościa procesów prowadzacych do rozwoju ryftu Gregory'ego, stanowiacego segment wschodnioafrykańskiego systemu ryftowego. Należy on do jednego $z$ trzech ramion trójzłacza Afaru, ściśle genetycznie zwiąanego z ewolucją znajdującej się na tym obszarze plamy goraca. Z uwagi na swa wyjątkowa atrakcyjność geoturystyczna oraz bogactwo i różnorodność przyrody ożywionej, jak też unikatowe uwarunkowania antropogeniczne (archeologiczne odkrycia szczątków i śladów bytności naszych przodków dokumentujace ważny etap historii ludzkości) rejon ten zostat wpisany na Listę Światowego Dziedzictwa Kulturowego i Przyrodniczego UNESCO.

Słowa kluczowe: wulkany, Ngorongoro, Tanzania, Afryka, ryft Gregory'ego, wschodnioafrykański system ryftowy, atrakcje geoturystyczne (geologiczne)

\section{Introduction}

The Ngorongoro Crater is visited each year by hundreds of thousands of tourists from all over the world. Its main attractions include breathtaking richness of animate nature (Żaba, Gaidzik 2011a) and uniqueness and magic beauty of the landscape (Fig. 1). Within its limits one can observe numerous endemic and rare plant and animal species, frequently endangered by extinction like, e.g., black rhino. The presence of extremely exotic to a European autochthonous Maasai population and remarkable archaeological findings in the close proximity of the Crater, of undoubted cultural values, additionally contribute to the attractiveness of this object. Moreover, the Crater attracts visitors by its extremely interesting geological evolution, strongly related to processes active in the Gregory Rift, a segment of the eastern arm of the East African Rift System.

The Ngorongoro Crater is situated in northern Tanzania, in the Arusha province, close to the boundary with Kenya. It is located in the Crater Highlands, which form a part of the East African Highlands. Besides Ngorongoro, the highlands are dotted by numerous other, now mostly extinct shield volcanoes. Some of them (like, for instance, Empakai or Olmoti) are also in the form of volcanic calderas, although of considerably smaller sizes. From the geological point of view, the Ngorongoro Crater is placed within the Gregory Rift that forms the southern segment of the East African Rift System. 


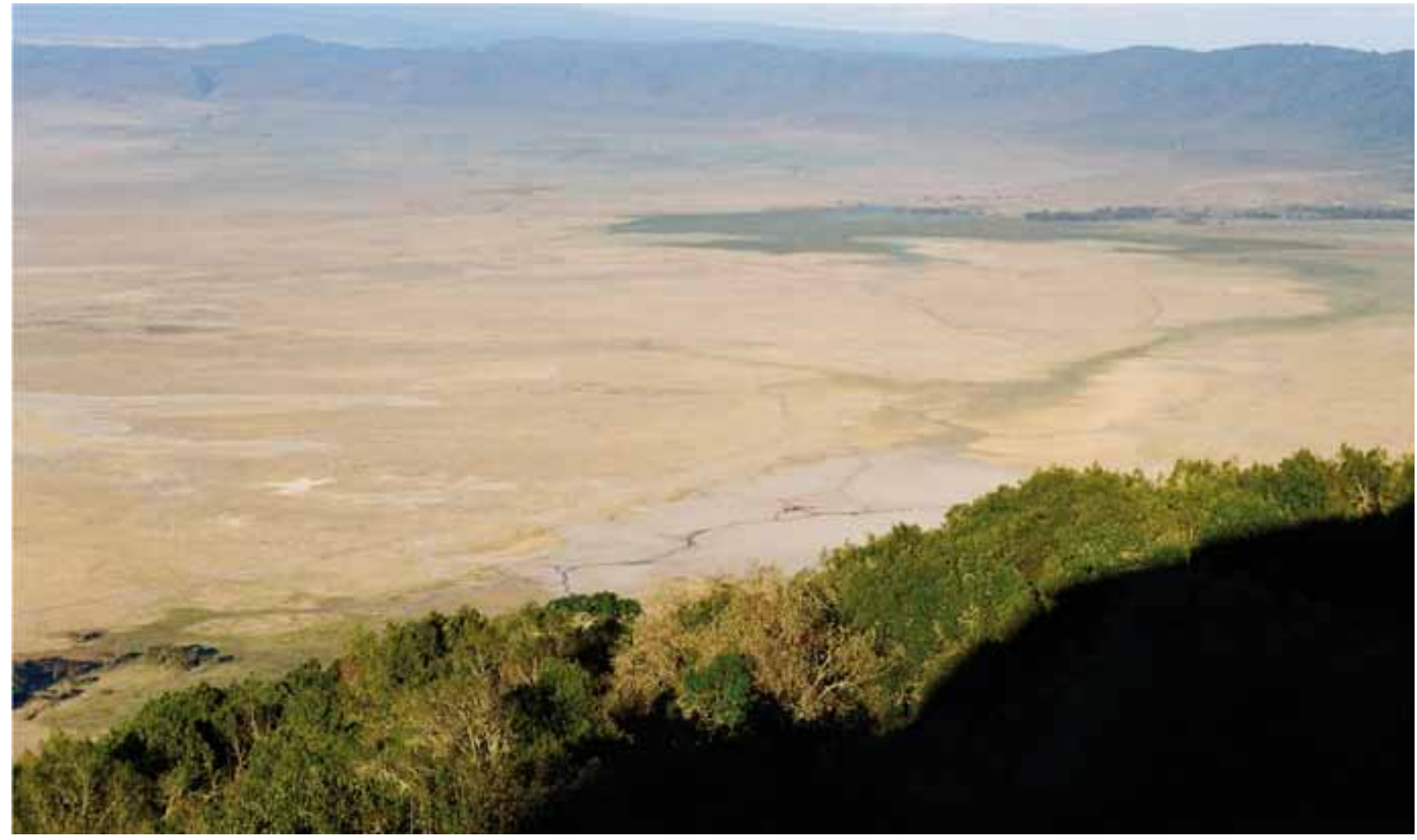

Fig. 1. The Ngorongoro Crater, view from the caldera rim, phot. J. Żaba • Widok na krater Ngorongoro z obrzeży kaldery, fot. J. Żaba

It is the world-largest, not destroyed and unflooded collapse caldera of an extinct shield volcano, whose walls rise a few hundred metres (500-600 m) above its floor and nearly $1.5 \mathrm{~km}$ above the rift valley bottom. The eruptive centre began to form in this area in the Pliocene, only some 3 millions of years ago, and remained active for nearly 250 thousands of years.

This paper is the second one from a series of three publications dealing with the Ngorongoro Crater, the greatest geotouristic attractions of the Gregory Rift and one of the greatest in the whole of East Africa. The first paper was devoted to geographical constraints, except geological setting of the Crater (Żaba, Gaidzik 2011a). The third paper, in turn, will focus on problems related to tourist infrastructure of the area as well as on related risks to both animate and inanimate nature (Żaba, Gaidzik 2011b).

\section{The Gregory Rift in the the East African Rift System}

The Ngorongoro Crater is situated inside the Gregory Rift, which represents the southern segment of the eastern arm of the East African Rift System extending submeridionally from the shores of the Red Sea and Gulf of Aden in the north to the coast of Indian Ocean in Mozambique (Fig. 2). Its total length amounts to $6,400 \mathrm{~km}$. The system includes two arms: the Eastern Rift and Western Rift, separated by the Lake Victoria.

The western arm (Western Rift Valley) extends from the upper reaches of the Alberta Nile and Upper Nile, via great African lakes: Albert, Edward, Kivu, Tanganyika, Rukua and Malawi (Nyasa), up to locality Beira in Mozambique, situated on the Indian Ocean coast.
The Eastern Rift Valley extends between the Bab-al-Mandab Strait, situated at intersection of the Red Sea and Gulf of Aden rifts, through the Turkana (Rudolf), Natron and Manyara lakes and Pangani River, to the Indian Ocean coast. A segment of this valley in Kenya and Tanzania is called the Gregory Rift.

Geomorphic equivalents of the East African Rift System are Great African Grabens. The widths of rift valleys in this system usually are between 40 and $60 \mathrm{~km}$, whereas their steep sides of the fault-scarp type frequently rise to $900 \mathrm{~m}$ and even 2,700 m (like the Mau escarpment in Kenya) above the rift bottom.

As far as tectonic setting is concerned, the East African Rift System represents one of the arms of the Afar triple junction, the origin of which is related to the underlying hot spot. Its development, strongly associated with the activity of a mantle plume, has been proceeding since the late Mesozoic up to Recent. The Miocene rifting (ca. 20 million years ago, i.e., $20 \mathrm{Ma}$ ) led to breakup of the Gondwana continental crust and formation of the Red Sea, Gulf of Aden and East-African rifts. Angles comprised between particular arms of this triple junction (Afar triple junction) are ca. $120^{\circ}$. More intensive development of the Red Sea and Gulf of Aden rifts led to breakup of the continental crust and formation of oceanic lithosphere in their central parts. These rifts mark at present a natural tectonic boundary between the African and Arabian plates. A much slower evolution of the East African Rift System caused that it is still an intracontinental rift underlain by continental lithosphere. This system represents the failed arm of a triple junction, like that of the Benue Trough in West Africa, on the Guinea Bay. This rift will probably turn into an aulacogen in the future (Żaba 2005). 


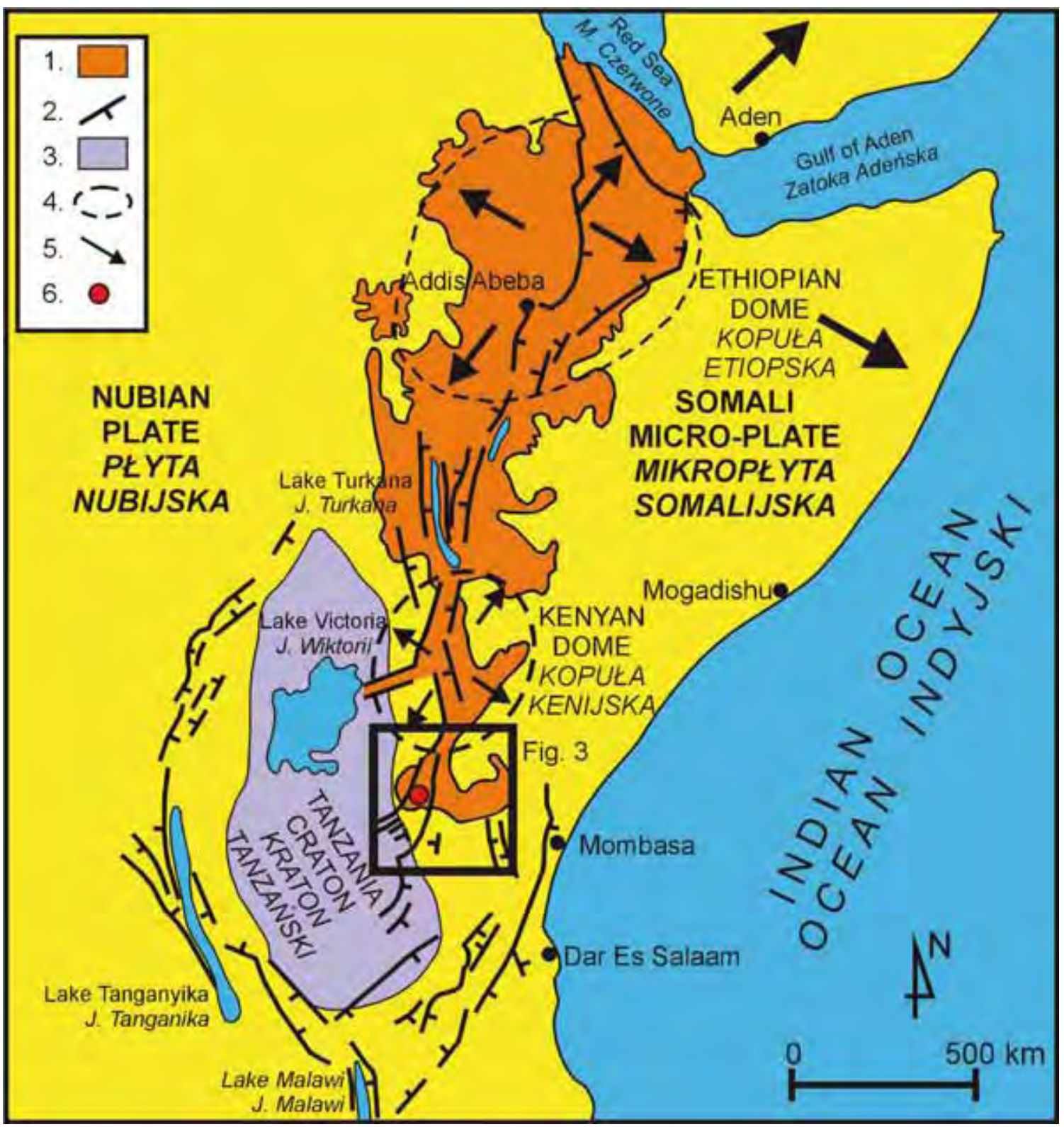

Fig. 2. Tectonics of the East Africa with the position of the Ngorongoro Crater (according to Dawson, 2008, modified). 1 - Ceinozoic Volcanics, 2 - major faults, 3 - approximate area of exposed Tanzania Craton, 4 - margins of Ethiopian and Kenyan Domes, 5 - direction of plate movement, 6 - Ngorongoro Crater • Pozycja krateru Ngorongoro na tle tektoniki Wschodniej Afryki (według Dawson 2008, zmienione). 1 - kenozoiczne skały wulkaniczne, 2 - ważniejsze uskoki, 3 - przybliżony obszar odsłoniętego kratonu tanzańskiego, 4 granice kopuł: etiopskiej i kenijskiej, 5 - kierunek ruchu płyt, 6 - krater Ngorongoro

The East African Rift System is typified by a very complicated structure. Besides being subdivided into two submeridional arms, it is also strike-parallel dismembered into segments displaced by either transversal or en echelon faults. Some segments of this system are composed of alternating half-grabens or asymmetric grabens (of opposite-facing asymmetry). Faults bounding half-grabens are arc-shaped in plan view, a feature strongly related to their listric geometry. Numerous subordinate horsts are present within the rifts (Żaba 2005). The rift sides are usually uplifted in respect to the central valley, being represented by horsts and half-horsts. Uplift of the footwalls of the East African grabens proceeded mainly in Late Neogene times (Burke et al. 1981) and in the Quaternary (Barker et al. 1988). The main episode of rifting within the Gregory Rift, responsible for the present-day character of this area, took place between 1.26 and 1.0 Ma (Foster et al. 1997).

The East African Rift System belongs to seismic areas of intensive volcanic activity. Particularly strong and frequent earthquakes typify the western arm. In the Gregory Rift, belonging to the eastern arm, earthquakes are less frequent and of smaller magnitudes, only sporadically attaining 5 degrees on the Mercalli intensity scale.

The Gregory Rift suffered from two episodes of increased volcanic activity. The older episode took place $1.2 \mathrm{Ma}$, preceding the main faulting. The younger episode, in turn, commenced ca. $1 \mathrm{Ma}$ and lasts until present day (Mollel et al. 2008). Still active geological processes in this area are testified to by the presence of active volcanoes: Meru and Oldoinyo Lengai. The former, situated some $130 \mathrm{~km}$ to the east of 
Ngorongoro (Fig. 3), rises to 4,565 $\mathrm{m}$ a.s.l. and represents the highest active volcano of continental Africa. Its last eruption took place in 1910 (Tab. 1). The Oldoinyo Lengai volcano, located in the Crater Highlands ca. $65 \mathrm{~km} \mathrm{NE}$ of Ngorongoro (Fig. 3), is the only one active carbonatite volcano on Earth (Tab. 1), the last eruptions of which took place at the end of 2007 and at the beginning of 2008. Nyiragongo (3,470 $\mathrm{m}$ a.s.1.) and Nyamuragira (3,056 $\mathrm{m}$ a.s.1.), situated in the Democratic Republic of Congo, are active volcanoes confined to the
Western Rift. The last eruption of Nyiragongo took place in 1982, and that of Nyamuragira - in 1977.

\section{Geological history and inheritance of the Ngorongoro Crater}

The origin of Ngorongoro volcano has been closely related with evolution of the East African Rift System, particularly the Tanzanian segment of the Gregory Rift.

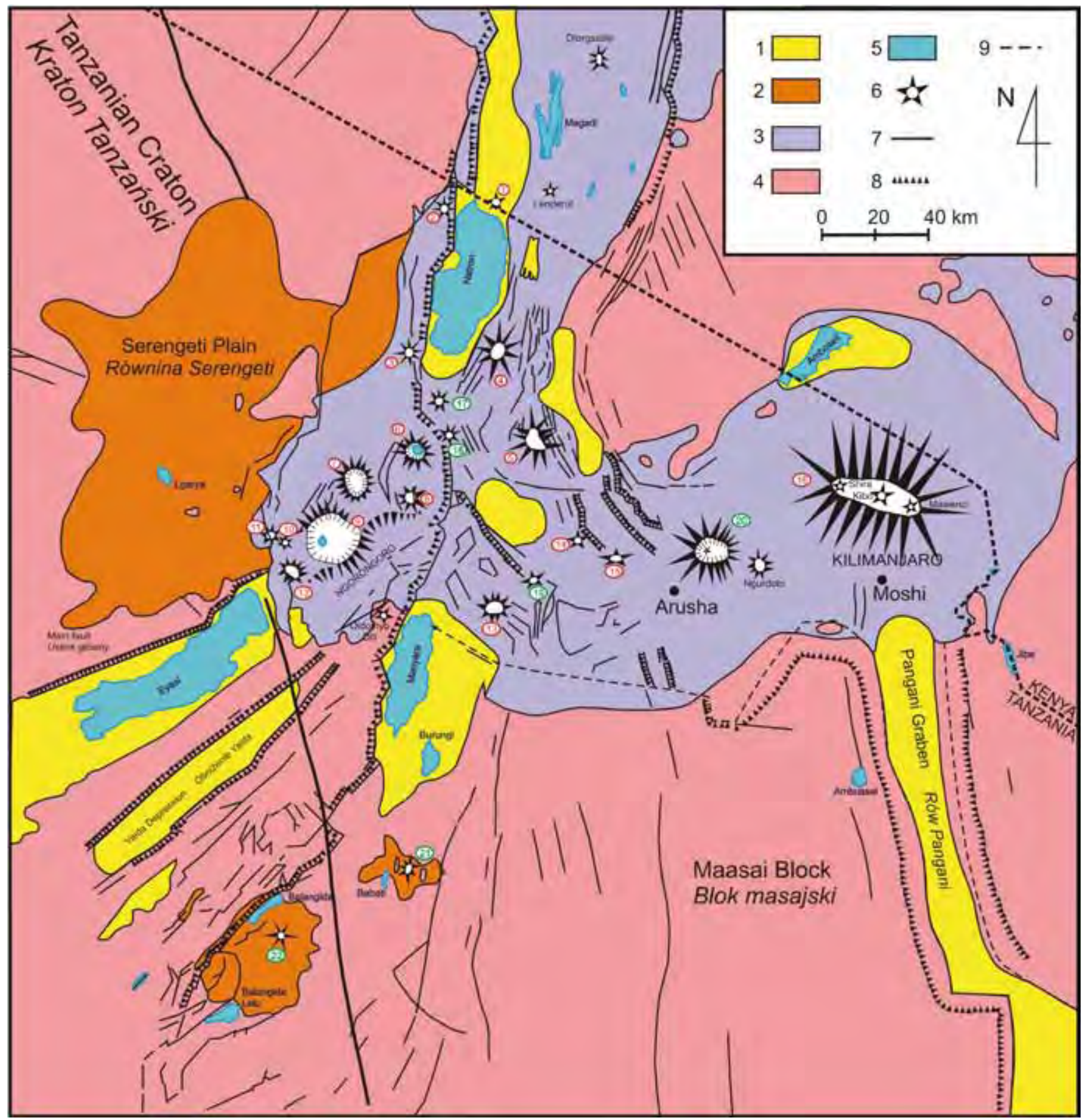

Fig. 3. Distribution of Neogene-Holocene faults and volcanic rocks in northern Tanzania and adjoining parts of southern Kenya (according to Dawson 2008, modified and simplified). 1 - modern alluvium, 2 - Neogene tuffs, 3 - Neogene lavas, 4 -basement, 5-lakes, 6 - volcanic cones, 7 - major faults, 8 - escarpments, 9 - international boundary • Rozmieszczenie neogeńsko-holoceńskich uskoków i skał wulkanicznych w północnej Tanzanii oraz na przyległych obszarach południowej Kenii (według Dawson 2008, zmienione i zgeneralizowane). 1 - współczesne aluwia, 2 - neogeńskie tufy, 3 - neogeńskie lawy, 4 - krystaliczne podłoże, 5 - jeziora, 6 - stożki wulkaniczne, 7 ważniejsze uskoki, 8 - skarpy morfologiczne (uskokowe), 9 - granica państwowa 
The eruptive centre in this area began to form in the Pliocene, more than 2 million years ago, and remained active for nearly 250 thousands of years (Mollel et al. 2008). It belongs to vast shield volcanoes of the Crater Highland, shaped during an early stage of volcanism (Tab. 1).

Although the oldest rocks building the Ngorongoro volcano are less than 2.5 million years old, it seems necessary to review geological evolution of the host area in order to understand the volcano's history. This evolution began in ancient times, probably more than 2 billion years ago.

\section{Formation of crystalline basement}

Geological history of the area presently occupied by the Ngorongoro caldera probably commenced more than 2 billion years ago with deposition of clastic sediments, from which the oldest sedimentary rocks were formed, represented mainly by sandstones, siltstones and claystones (Fig. 4). During subsequent tectonic movements, these rocks became folded and metamorphosed due to increasing temperature and pressure under conditions of regional metamorphism, being turned into quartzites, gneisses and schists. Regional metamorphism was overprinted by thermal and metasomatic metamorphosis associated with granitoid intrusions that affected this area. The intruding magma supplied abundant new chemical compounds that led to changes in chemical and mineral composition of pre-existing rocks (Fig. 4; Pickering 1994).

The oldest stage of evolution of the area terminated with intensive tectonic movements, during which folded and metamorphosed rocks became uplifted. At the boundary between gneisses and granites, the principal shear zone was formed, within which the rocks were crushed, powdered and displaced (Pickering 1994). In this way, under conditions of dislocation metamorphism, cataclastic rocks were formed being represented by mylonites as well as - at some places - cataclasites and tectonic breccias.

\section{Denudation}

Intensive denudation processes affected the area between Precambrian and Miocene times. It is the longest stage in geological history of the Ngorongoro Crater and the only one, during which exogenic processes dominated so decisively. No important tectonic movements were detected in this long period of time. Previously uplifted rocks were being intensely denuded and the terrain became gradually destroyed and smoothed out. The lack of vegetation cover additionally contributed to increased rock susceptibility to denudation. The bedrock was affected by such processes, as: physical and chemical weathering, mass movements, fluvial erosion, corrosion and deflation.

Fig. 4. Evolution of the Ngorongoro Crater (according to Pickering 1994, modified and supplemented). Explanations: pink - Precambrian metamorphic rocks, red - Precambrian granitoids, dark brown - older volcanic cones, orange - younger volcanic cones, dark grey - escarpments - Ewolucja krateru Ngorongoro (według Pickering 1994, zmienione i uzupełnione). Objaśnienia: różowy prekambryjskie skały metamorficzne, czerwony - prekambryjskie granitoidy, ciemnobrązowy - stożki wulkaniczne starszego etapu, pomarańczowy - stożki wulkaniczne młodszego etapu, ciemnoszary - skarpy ryftowe

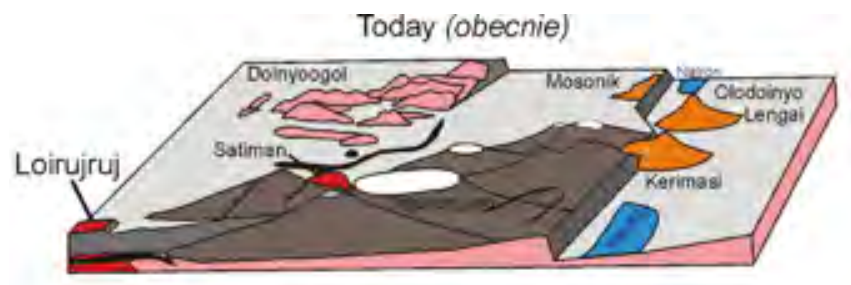

\section{Second stage of riftogenesis (drugi etap ryftogenezy)}

2-1 Ma - Pliocene/Pleistocene (pliocen/plejstocen)

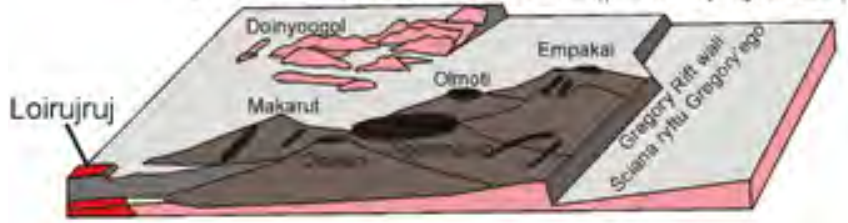

Early volcanism (wczesny wulkanizm) 5-2 Ma - Pliocene (pliocen)

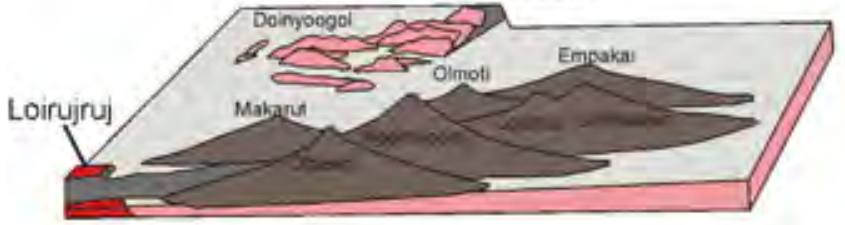

First stage of riftogenesis (pierwszy etap ryftogenezy)

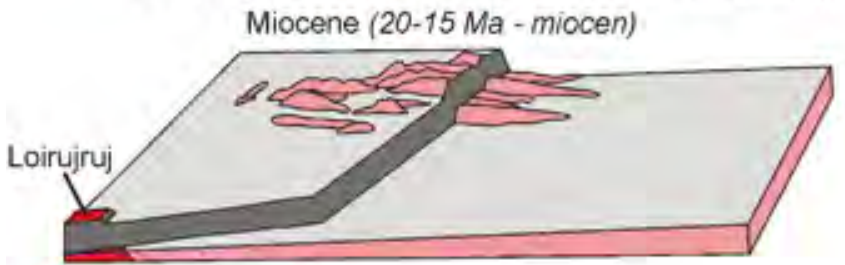

Peneplain (peneplena)

Early Miocene (wczesny miocen)

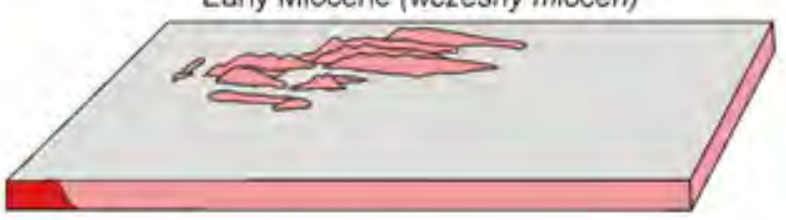

Uplift and denudation (wypietrenie i denudacja)

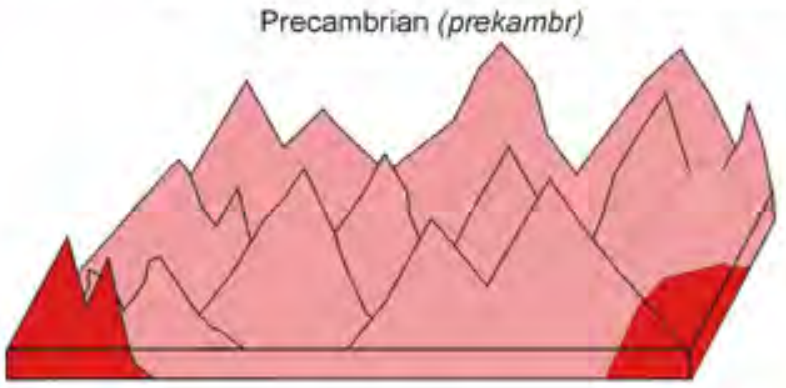

Magmatism and metamorphism (magmatyzm i metamorfizm;

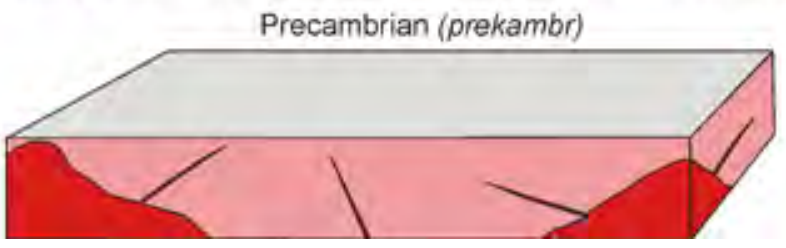




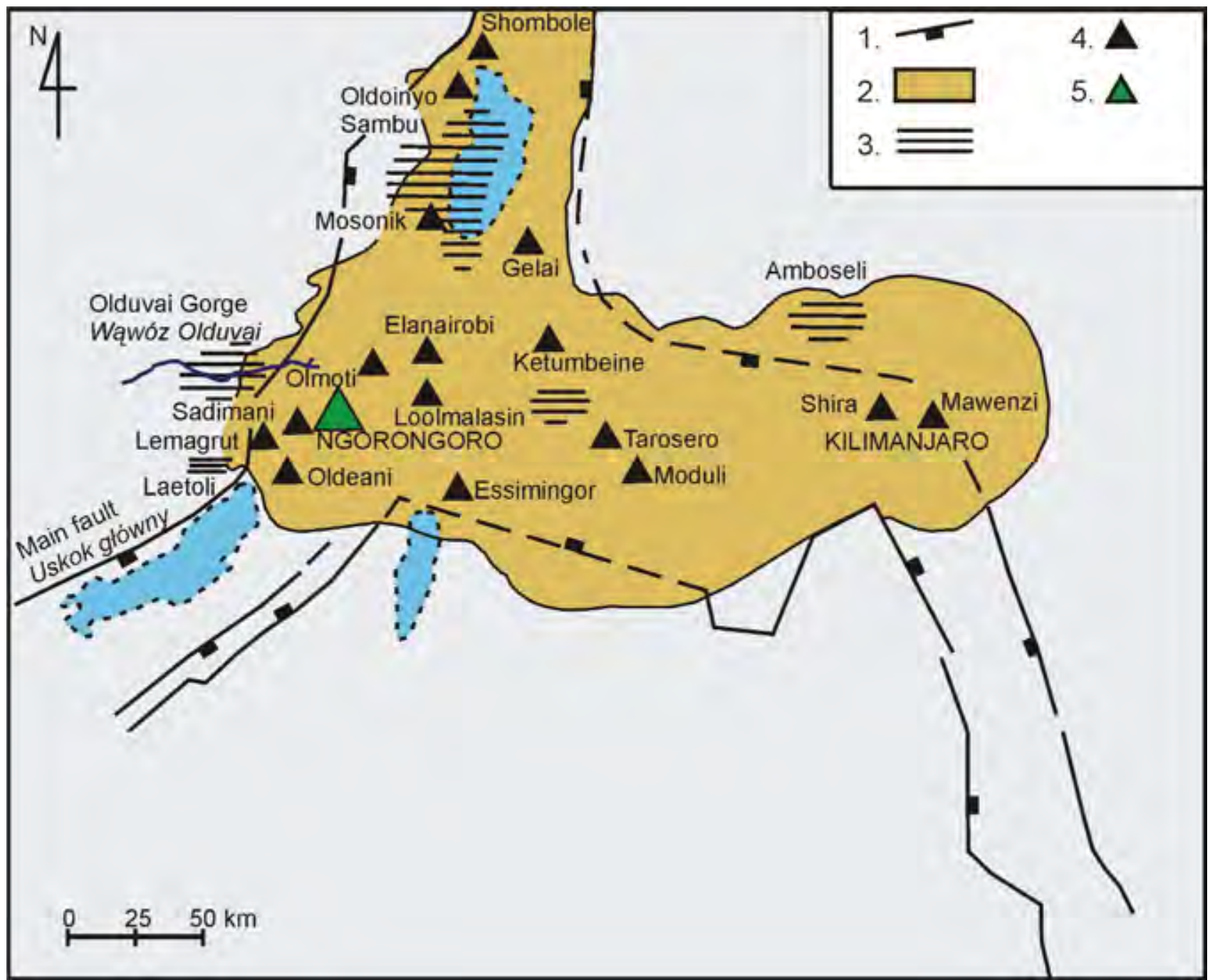

Fig. 5. Distribution of the older extrusive volcanic centres and areas of Plio-Pleistocene sedimentation (according to Dawson 2008). $1-$ main faults, 2 - areal extent of lava extrusions, 3 - areas of sedimentation, 4 - Late Tartiary-Early Pleistocene major volcanic centres, 5 - Ngorongoro volcano • Rozmieszczenie starszych wulkanów ekstruzywnych i obszarów plio-plejstoceńskiej sedymentacji (według Dawson 2008). 1 - główne uskoki, 2 - wulkanity (zasięg wypływów lawy), 3 - obszary sedymentacji, 4 - wulkany (późnotrzeciorzędowe-wczesnoplejstoceńskie), 5 - wulkan Ngorongoro

Initially, the landscape probably resembled that of presentday young Alpine mountain ranges (Fig. 4), dominated by steep-sided summits, rocky crests, and V-shaped deeply-cut fluvial valleys. Talus cones were shed from free faces. Vegetation appeared in this area ca. $400 \mathrm{Ma}$, providing some protection against destructive erosion. Nevertheless, biogenic weathering contributed at the same time to enhanced intensity of rock disintegration.

Long-term denudation led to destruction of precipitous rocky mountains of the Alpine type and formation of a slightly undulated peneplain (Fig. 4). Moreover, erosion contributed to separation and exposure of most resistant Precambrian crystalline rocks. Monadnocks shaped in this way are still visible in the present-day topography. These are presented by the Doinyoogol Hills and isolated Lemuta, Loirujruj, Naibor and Naibardad hills, built up of Precambrian igneous and metamorphic rocks (Pickering 1994).

\section{The first rifting stage}

In the Miocene, ca. $20 \mathrm{Ma}$, intensive rifting began leading, i.a., to formation of the Crater Highlands and Ngorongoro volcano and, later, Ngorongoro caldera. Processes associated with the activity of a mantle plume were responsible for formation of a major fault that strikes at present along the NW shore of the Eyasi Lake and then continues to the north dissecting the Doinyoogol Hills (Figs. 4, 5). The eastern side of this fault became lowered by some $1,000-2,000 \mathrm{~m}$ in respect to the western one. The faulting produced a huge fault scarp. Moreover, in the SW part of the area, a crustal fragment bounded by the main fault and two subsidiary faults became uplifted as the Loirujruj block (Fig. 4; Pickering 1994).

\section{Older stage of volcanism and formation of the Crater Highlands}

The oldest episode of volcanism in the area was restricted to terrains situated to the east of the main fault, formed during the first rifting stage (Fig. 4). This episode was represented by chemically inactive and basic lavas erupting from elongated fissures, opened during faulting. The lavas were typified by minor viscosity and could have spread over long distances forming vast basalt covers (the so-called basalt traps) in the eastern, lowered rift side, extending up to Kilimanjaro. 


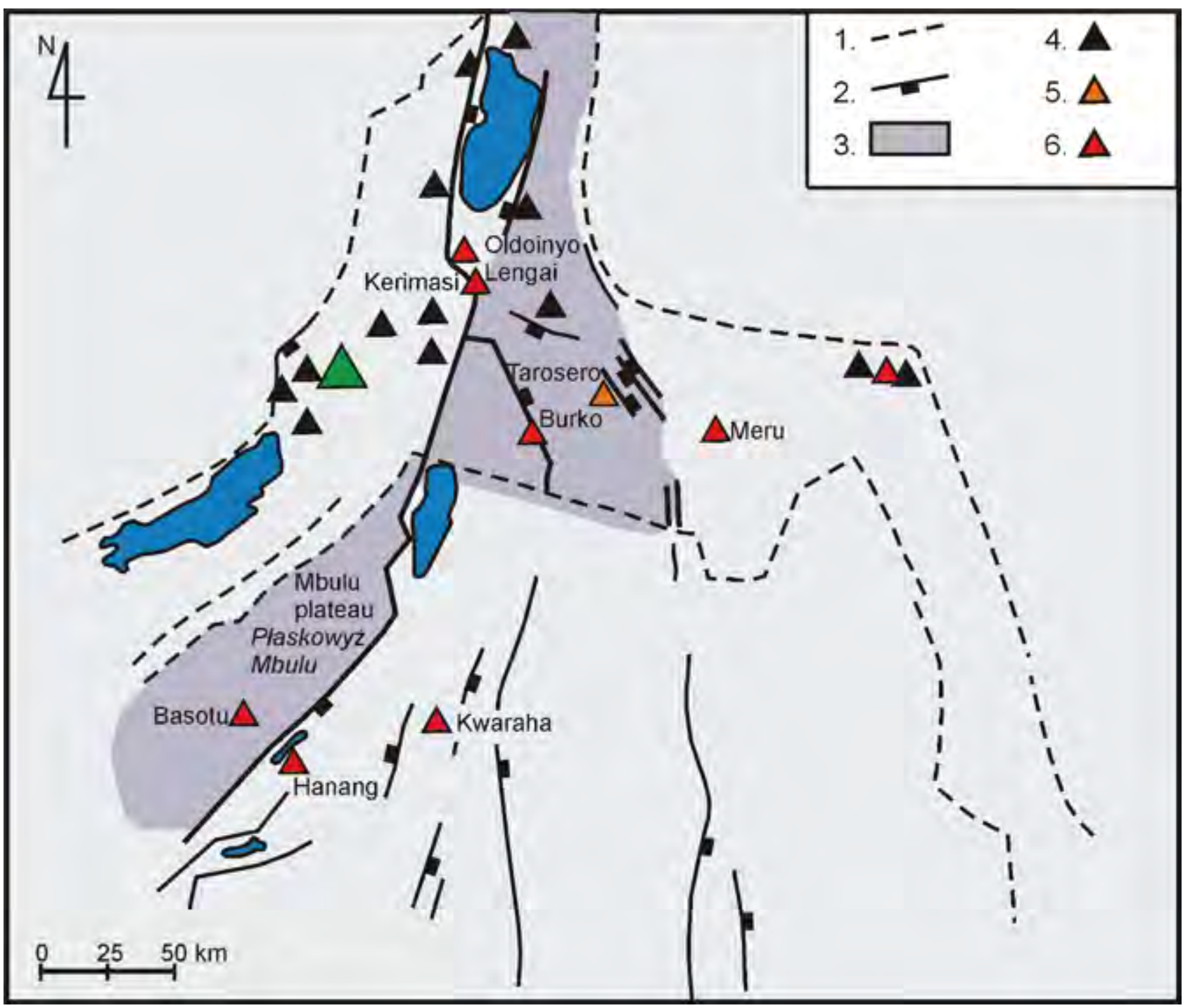

Fig. 6. Distribution of the main faults and younger extrusive volcanoes (according to Dawson, 2008). 1 - main, older faults, 2 - main Upper Pleistocene faults, 3 - areas of intense minor faulting, 4 - Late Tartiary-Early Pleistocene major volcanic centres (green - Ngorongoro volcano), 5 - older volcanoes that continue to erupt in the Pleistocene, 6 - major Upper Pleistocene or Recent volcanic centres • Rozmieszczenie głównych uskoków oraz młodszych wulkanów ekstruzywnych (według Dawson, 2008). 1 - ważniejsze starsze uskoki, 2-główne późnoplejstoceńskie uskoki, 3 - obszary intensywnego, podrzędnego uskokowania, 4 - wulkany późnotrzeciorzędowo-wczesnoplejstoceńskie (na zielono zaznaczono wulkan Ngorongoro), 5 - wulkany starsze (aktywne również w plejstocenie), 6 - ważniejsze wulkany o aktywności późnoplejstoceńskiej lub/i współczesnej

Lava expansion to the west was blocked by the main rift escarpment (Fig. 4), which, due to flooding from below by successive lava flows and erosion from above by rivers (e.g., Karian and Togom), became gradually smoothed out and finally disappeared (Pickering 1994).

More than 2 million years ago, in the Pliocene, the preexisting fissure volcanism became transformed into chimney volcanism. Up to now, seven such chimneys - eruption centres - survived in the area. From each centre lava flowed in all directions building vast summits of shield volcanoes, which, when growing, were merging together. In this way, extensive shield volcanoes (mostly basalt-trachyandesite ones) of the Crater Highlands, like: Empakai, Olmoti, Loolmalasin, Ngorongoro, Lemagrut, Sadiman, and Oldeani originated (Tab. 1, Fig. 5). Moreover, volcanic cones located outside the Crater Highlands: Shombole, Oldoinyo Sambu, Mosonik, Gelai and Ketumbeine, were formed. This period witnessed as well the formation of great eruptive centres of Essimingor, Tarosero, Monduli, and Kilimanjaro (Tab. 1, Fig. 5; Dawson 2008).

The lavas became less viscous and mobile with time and volcanoes started to reveal explosive activity. Most probably, the earliest volcanic activity of this type was initiated in the Ngorongoro centre. The most recent age determinations of volcanic rocks of this volcano indicate that it remained active for nearly 250 thousand years: from 2.25 \pm 0.02 to $2.01 \mathrm{Ma}$. It was previously accepted that volcanic activity started ca. 2.5 Ma (Tab. 2 Mollel et al. 2008). Volcanoes growing at that time were much higher than at present. The Ngorongoro volcano probably attained altitudes of ca. 4,500-5,000 m a.s.l., rising nearly 3,000 $\mathrm{m}$ above the present-day caldera's margin. However, a gigantic eruption at that time destroyed the top part of the Ngorongoro volcano and the western slopes of the Oldeani volcano. 


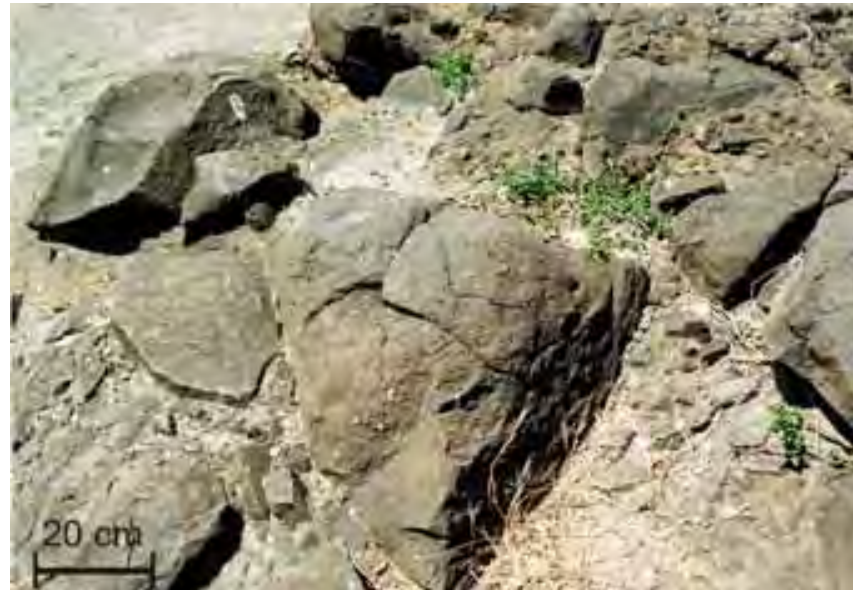

Fig. 7. Intensively fractured basaltoids on the floor of the Ngorongoro Crater, phot. J. Żaba Intensywnie spękane bazaltoidy na dnie krateru Ngorongoro, fot. J. Żaba

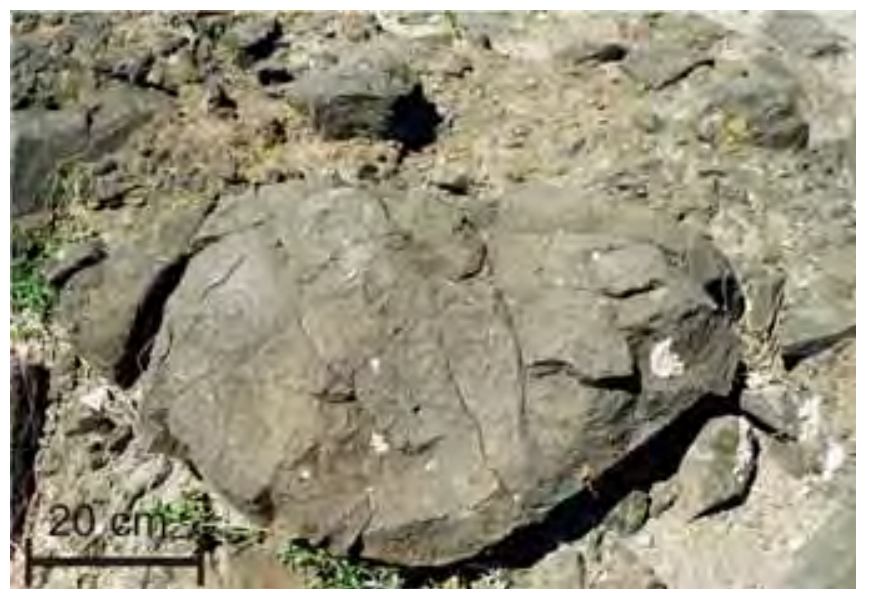

Fig. 8. Heavily fractured basaltoid volcanic bomb on the floor of the Ngorongoro Crater. The form is up to $1 \mathrm{~m}$ long and about $30 \mathrm{~cm}$ width, phot. J. Żaba • Silnie spękana (spękania nieciosowe) bazaltoidowa bomba wulkaniczna na dnie krateru Ngorongoro (o długości $1 \mathrm{~m}$ i szerokości około $30 \mathrm{~cm}$ ), fot. J. Żaba

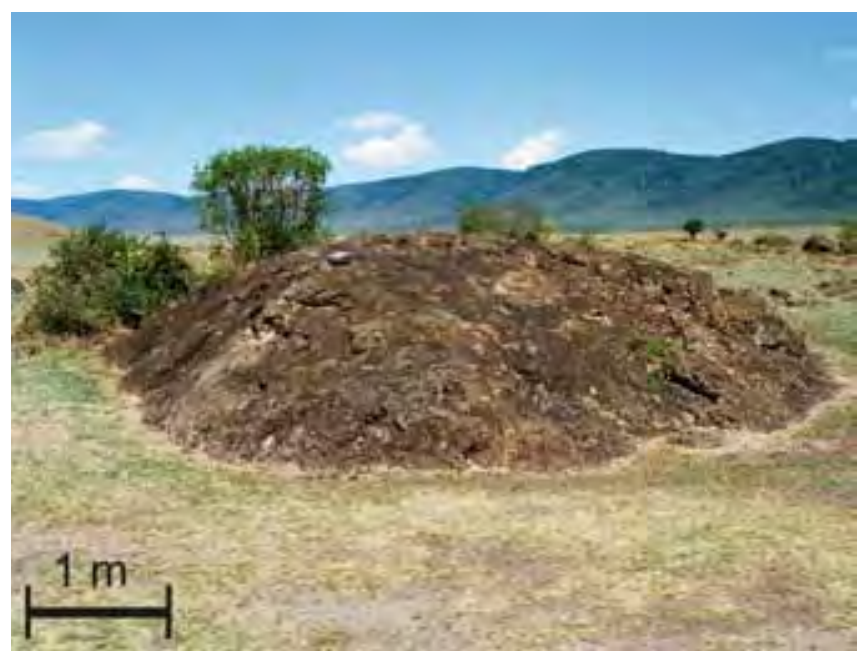

Fig. 9. Small and distinctive mound (up to $2 \mathrm{~m}$ height above the Crater floor) made of basaltoid lava, formed as the effect of the volcanic processes, as well as weathering in tropical climate, phot. J. Żaba • Niewielki i charakterystyczny pagórek (o wysokości $2 \mathrm{~m}$ ponad dno krateru) zbudowany z lawy bazaltoidowej stanowiący efekt procesów wulkanicznych oraz wietrzenia w klimacie tropikalnym, fot. J. Żaba
Minor volcanic explosions led to formation of two calderas within the Losirua volcano (Pickering 1994).

At the end of this stage, location of volcanic activity to the east of the main fault became drastically changed and basaltoid lava flows filled nearly completely the old rift valley.

\section{The second rifting stage - formation of the Ngorongoro Crater}

The second stage of rifting was closely associated with faulting responsible for formation of the Gregory Rift valley between 1.26 and 1.0 Ma (Mollel et al. 2008). The rift valley originated along the newly-formed main normal fault, striking N-S, and located along the eastern boundary of the Crater Highlands (Fig. 4). Formation of this fault led to partial destruction of the eastern volcanic cones in the area. Like in the first stage of rifting, the eastern side became relatively subsided and the western one was uplifted. On the latter, numerous volcanic cones, including Ngorongoro, were situated. The fault amplitude can be approximated by present-day relief, frequently exceeding $1,000 \mathrm{~m}$.

In this stage, the Ngorongoro eruption centre became surrounded by numerous fractures and concentric faults. Intensive volcanic activity, lasting for over 200 thousands of years, led to emptying magma chamber below the volcano. This resulted in collapse of the volcano's central part and formation of a gigantic collapse volcanic caldera, presently known as the Ngorongoro Crater. Analogous processes, although on a much smaller scale, affected also the Olmoti and Empakai volcanoes where collapse calderas were formed as well (Olmoti Crater and Empakai Crater; Fig. 4).

Gigantic collapse processes in the Crater Highlands led to formation of numerous subsidiary faults: 1 - bordering the Bulbul Lake from the west, 2 - cutting the Losirua peak, and 3 - controlling origin of a valley between the Losirua peak and the eastern Loolmalasin range. Moreover, structures of this type were formed as well on slopes of numerous volcanoes located in the Crater Highland, like: Ngorongoro, Makarut and Olmoti. Minor faults produced at that time are also present in the Tepess and Kilim-Tembo regions (Pickering 1994).

In the Gregory Rift valley, produced during the second stage of rifting, the most important water reservoirs of this region originated: the Manyara and Natron lakes with Engaruka and Olmkoko basins, while in the Crater Highlands the Ngorongoro, Malanja, Bulbul and Empakai lakes were formed (Pickering 1994).

\section{Younger stage of volcanism}

The younger stage of volcanism, typified by explosive activity, was initiated ca. $1 \mathrm{Ma}$ already after formation of the Gregory Rift valley and huge volcanic calderas, and lasts until now. The most important stratovolcanoes of the area were then formed: Meru, Monduli, Oldoinyo Lengai, Kerimasi, Burko and Kwaraha, along with minor tuff cones and craters (Tab. 1, Figs. 4, 6). These volcanoes are mostly built up of olivine-less nephenilites and phonolites. The discussed stage was also characterized by carbonatite eruptions of the Oldoinyo Lengai, Kerimasi, Kwaraha and Hanang volcanoes (Tab. 1), situated either within fault zones or to the east of the most important faults bordering the Gregory Rift (Foster et al. 1997). 


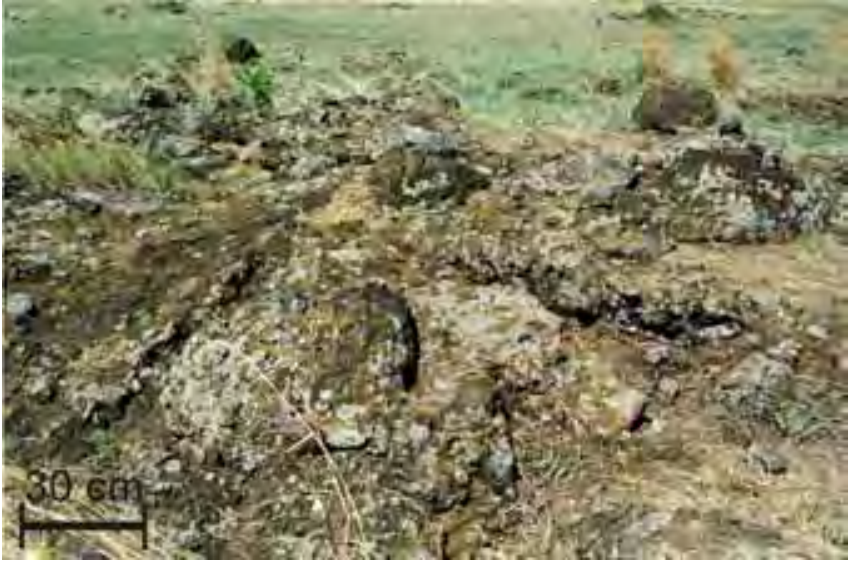

Fig. 10. Fragment of form presented on fig. 9; strongly fractured and weathered basaltoids are commonly inhabited by the lichen flora, phot. J. Żaba • Fragment formy uwidocznionej na fig. 9; silnie spękane i zwietrzałe bazaltoidy są intensywnie porastane przez florę porostów, fot. J. Żaba

Huge explosive eruptions of the Kerimasi volcano (2,607 m a.s.l.; Tab. 1; Dawson 2008) covered large areas with volcanic ash and dust bearing a large amount of calcite. Calcareous tuffs, a product of this activity, occur, i.a., in: 1 - the Gregory Rift valley around Kerimasi and Bulbul, 2 -in the Balbal region, 3 - in the western part of Ngorongoro (filling nearly completely the Engitati Hill crater), 4 - in the Olduvai Gorge, and 5 - upon vast areas of the Salei and Serengeti plains, particularly at the feet of the Doinyoogol Hills where their thickness largely exceeds $100 \mathrm{~m}$. Calcareous tuffs originating from the presently extinct Kerimasi volcano form silty ground upon the Serengeti and Salei plains (Pickering 1994).

When the Kerimasi volcano concluded its activity, another volcano, Oldoinyo Lengai (2,890 m a.s.l.; Tab. 1; Dawson 2008) situated $11.3 \mathrm{~km}$ to the north, became active. Intensive eruptions of this stratovolcano quickly led to formation of a symmetric cone composed of agglomerates, tuffs and lavas. It is the only active carbonatite volcano on Earth (Pickering 1994; Dawson 2008).

Traces of minor volcanic activity (of explosive character) in this stage were also marked inside the newlyformed Ngorongoro caldera in the form of small mounds composed of pyroclastic material. These landforms occur along the caldera's margins, at the feet of steep walls (Pickering 1994). A good example of such volcanic activity is provided by the Engitati Hill, located inside the Ngorongoro caldera, composed of pyroclastic materials represented by volcanic ashes, dust and tuffs (scoria) as well as agglomerates. The top part of this hill became later partly destroyed due to a violent volcanic explosion. A vast, shallow crater was formed and the landform became saucer-shaped.

Characteristic, small hills were also formed in other regions of the Crater Highlands (e.g., in the Melenda region and on slopes of Oldeani volcano) and the Gregory Rift valley. These landforms, composed of lava, are strongly associated with minor fault scarps, along which effusive eruptions tended to concentrate at that time.

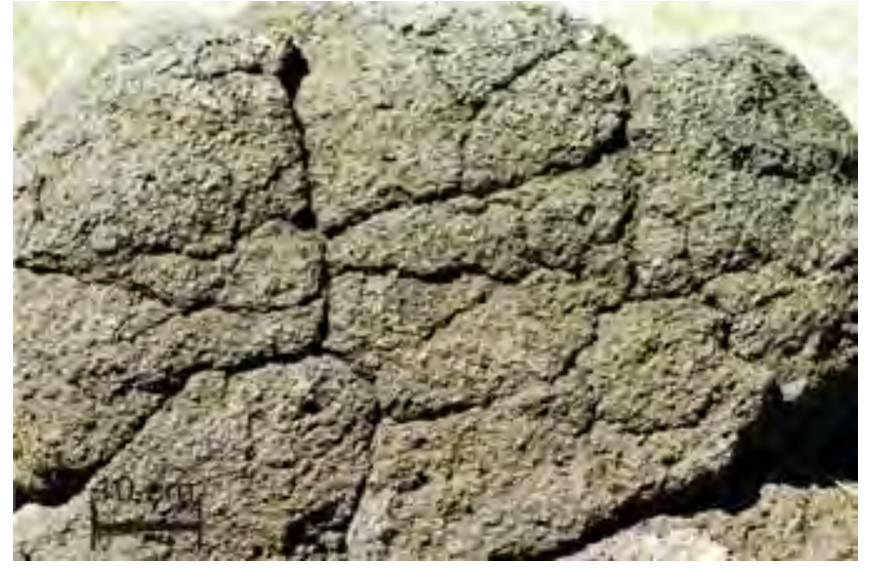

Fig. 11. Fragment of the irregularly fractured basaltoid lava (characteristic rough surface caused by the weathering) from the Ngorongoro volcano, phot. J. Żaba • Fragment nieregularnie spękanej lawy bazaltoidowej (o charakterystycznej, nierównej powierzchni spowodowanej wietrzeniem) z wulkanu Ngorongoro, fot. J. Żaba

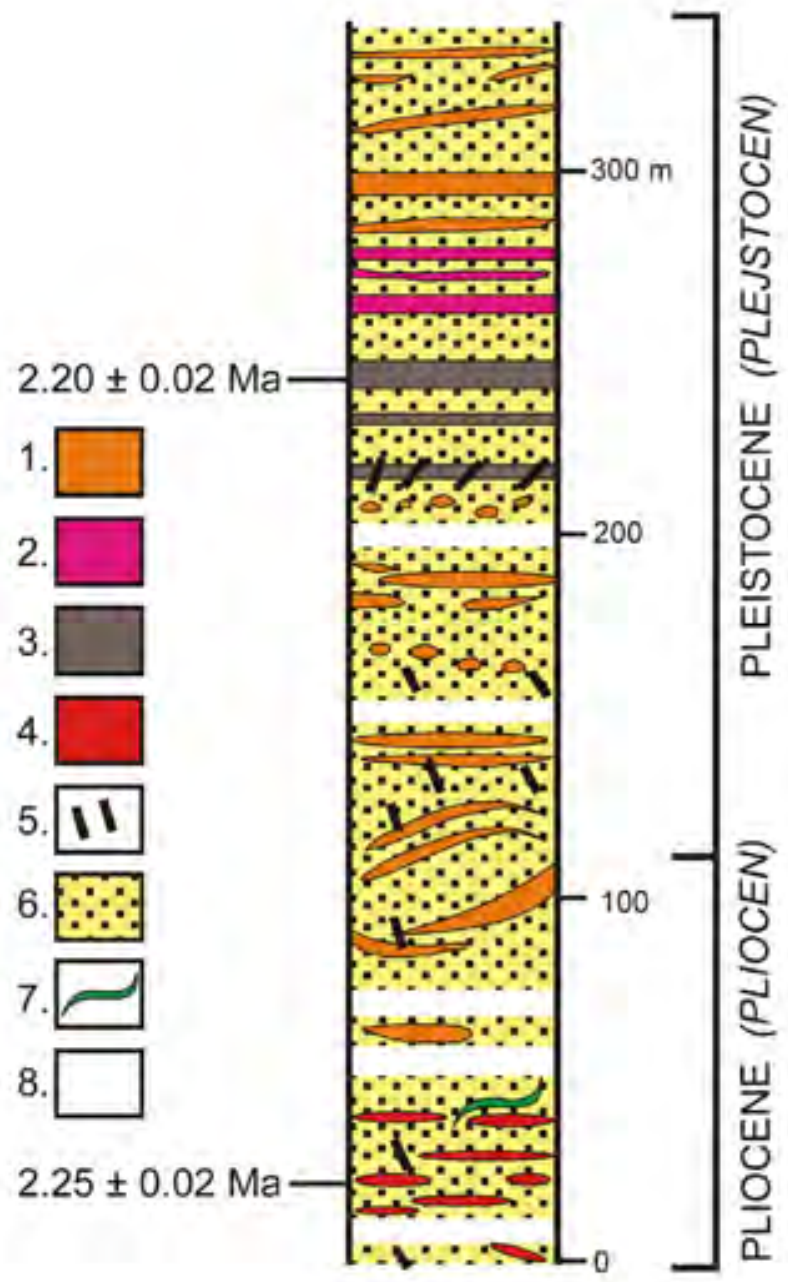

Fig. 12. Lerai section in the Ngorongoro Crater (according to Grommé et al., 1970). 1 - fine-grained trachyandesite, 2 - porphyritic trachybasalt, 3 - porphyritic olivine basalt, 4 - porphyritic trachydacite, 5 - dykes, 6 - tuff and agglomerate, 7 - welded tuff, 8 - no or poor exposure - Profil Lerai w kraterze Ngorognoro (według Grommé i in., 1970). 1 - drobnoziarnisty trachyandezyt, 2 - porfirowy trachybazalt, 3 - porfirowy bazalt oliwinowy, 4 - porfirowy trachydacyt, 5-dajki, 6-tuf i aglomerat, 7 - tuf spieczony, 8 - brak danych (słabe odsłonięcie) 
At the end of this stage, both fault scarps and slopes of volcanic cones in the Crater Highlands were eroded and intensely dissected by perennial and periodic streams, leading to formation of numerous fluvial valleys and gullies, at the mouths of which alluvial fans composed of coarse-clastic sediments were frequently formed. Finergrained material was transported away over longer distances and deposited in depressions of various types. This resulted, i.a., in filling and size reduction of the majority of lakes like, for instance, Eyasi, Manyara and Natron (Pickering 1994).

\section{Rocks of the Ngorongoro Crater and its surroundings}

The Ngorongoro Crater is composed of relatively young rocks, the oldest of which formed in Pliocene times, ca. $2 \mathrm{Ma}$ (Mollel et al. 2008). These are represented, first of all, by basaltoid lavas showing olivine basalt, trachybasalt and trachyandesite composition (Figs. 7, 8, 9, 10, 11). Ignimbrites dominate within products of the youngest eruptions (Tab. 2; cf. Dawson 2008). Other volcanic rocks, like: hawaiites (James 1966, vide Dawson 2008), basanites, tephrites, phonotephrites (phonolitic tephrites) and mugearites (Wood 1968, vide Dawson 2008) occur in the crater as well.

According to older data, the Ngorongoro volcanic activity lasted between 2.5 and 2 Ma (Tab. 2; Grommé et al. 1970). The most recent ${ }^{40} \mathrm{Ar} /{ }^{39} \mathrm{Ar}$ radiometric determinations did not confirm completely previous results (Mollel et al. 2008) and point to volcanic activity between 2.25 and ca. $2 \mathrm{Ma}$.

A nearly complete lithostratigraphic section of rocks building the Ngorongoro Crater can be examined, i.a., along the Lerai road, an exit road from the Crater (Fig. 12).

A large part of the Ngorongoro Crater is most probably underlain by tuffs. The caldera's floor is dotted by numerous small cones composed of pyroclastic material. One of them is the Engitati Hill where basalts of a characteristic texture pointing to subaqueous eruptions were found (Pickering 1965, vide Dawson 2008).

The southern and eastern shores of the salt Makat Lake, situated in the Ngorongoro caldera, expose lacustrine loams, marly limestones and tuffs, the radiocarbon age of which ranges between 27,990 \pm 500 and 24,400 \pm 690 years (Hay 1976).

The basement of the Ngorongoro volcano is built up of old crystalline rocks, which can be examined in the Doinyoogol Hills, situated a dozen or so kilometres to the north and northwest of the Crater. Top parts of these hills are composed of Precambrian white and red quartzites underlain by gneisses and mica schists. Precambrian metamorphic rocks are also exposed to the south-west of the Crater, in a scarp rising above the Eyasi Lake, situated at the base of the Loirujruj mountains, as well as in a large part of an isolated mountain in the Lemuta area. Igneous rocks, in turn, represented by granites, occur in the Loirujruj block (Fig. 3).

\section{Summary}

The Ngorongoro Crater is typified by great, unique on a global scale natural values (including geological ones) and, hence, exceptional geotouristic potential (Żaba, Gaidzik 2011b). Principal geological values of the area include numerous volcanic landforms, first of all the world-largest not destroyed and unflooded caldera of the Ngorongoro volcano, characterized by unforgettable landscape scenery that provides aesthetic experiences. The caldera bears numerous salt and freshwater lakes as well as tuff cones of minor explosive volcanoes. A great variety of volcanic and pyroclastic rocks build different geologic and geomorphic forms. The Ngorongoro caldera is accompanied by other shield and stratovolcanoes, many of them showing different manifestations of volcanic activity. Nearby, the only active carbonatite volcano on Earth and a huge fault scarp of a gigantic rift valley, a segment of the world-largest continental rift system, are located. Processes active in this region are of fundamental importance for development of the crust. Besides esthetic values providing unforgettable experience and emotions, the area also possesses exceptionally great geo-educational potential.

Taking into account exceptional attractiveness of the Ngorongoro Crater, this object together with surrounding areas was given in 1959 a status of the Ngorongoro Conservation Area (NCA). It was also included in the list of UNESCO World Cultural and Natural Heritage Sites, initially due to its natural values and then, owing to importance of archaeological findings, it was re-classified in 2010 as a mixed object. 


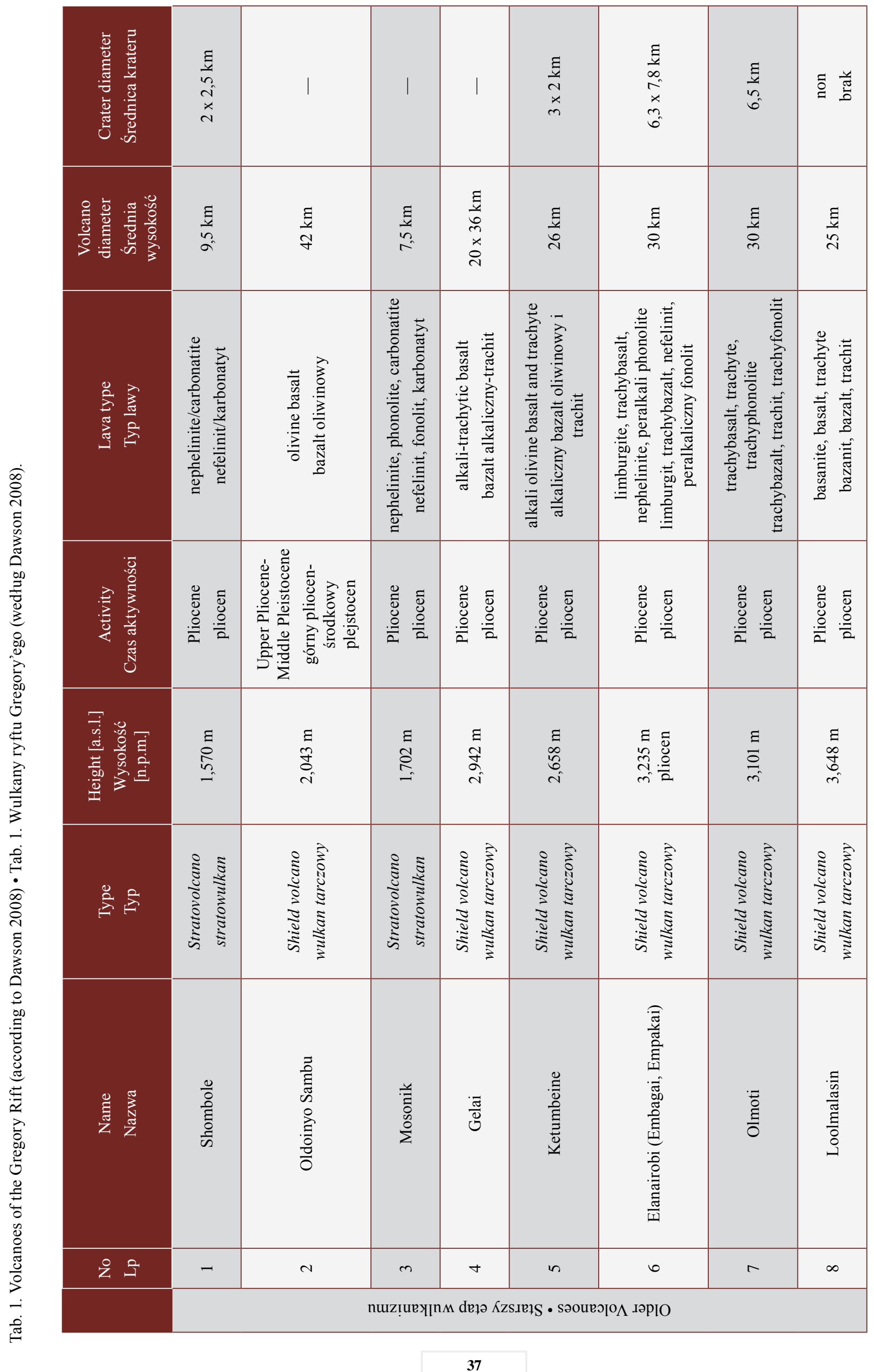




\begin{tabular}{|c|c|c|c|c|c|c|c|}
\hline 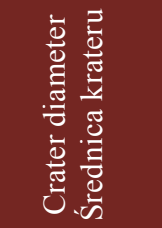 & 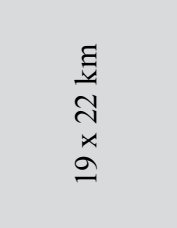 & 㻤 & ప్ & $\frac{\Xi}{n}$ & | & | & | \\
\hline 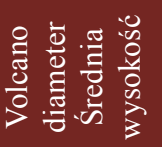 & $\frac{\Xi}{\sim}$ & $\frac{\Xi}{\stackrel{\Xi}{\sim}}$ & $\frac{\Xi}{6}$ & $\frac{\text { g }}{\stackrel{\sim}{\sim}}$ & $\frac{\Xi}{\underline{\Xi}}$ & $\frac{g}{n}$ & 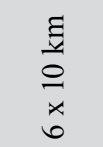 \\
\hline 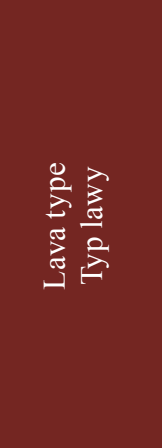 & 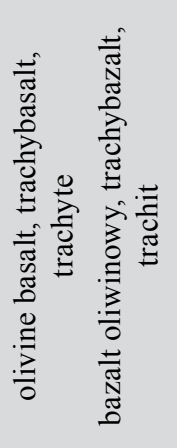 & 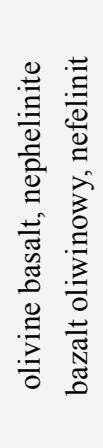 & 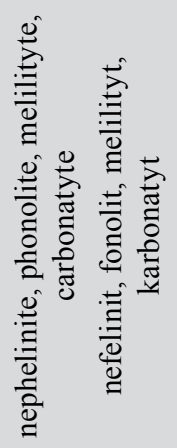 & 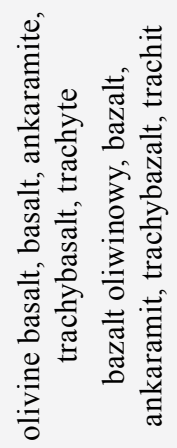 & 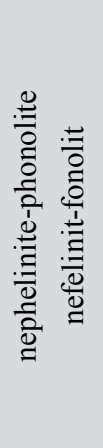 & 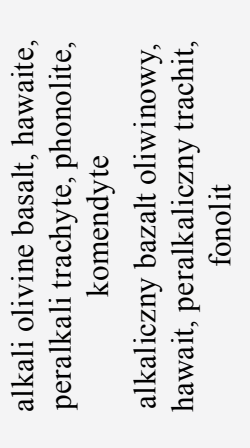 & 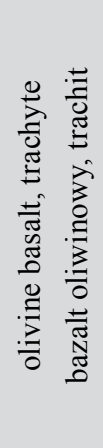 \\
\hline 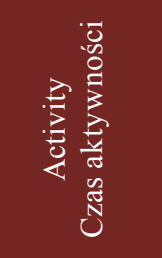 & 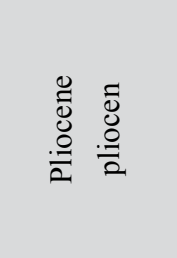 & 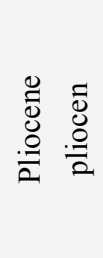 & 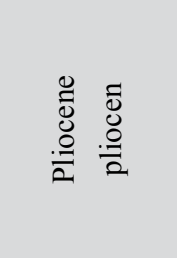 & 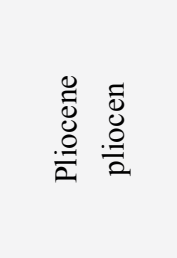 & 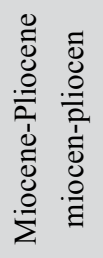 & \begin{tabular}{ll}
$\mathscr{0}$ & $\overline{0}$ \\
$\stackrel{0}{0}$ & $\stackrel{0}{0}$ \\
\hdashline & 0
\end{tabular} & 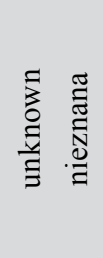 \\
\hline 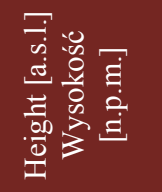 & $\begin{array}{l}\Xi \\
D \\
\infty \\
j \\
i\end{array}$ & $\begin{array}{l}\Xi \\
\stackrel{n}{m} \\
m\end{array}$ & 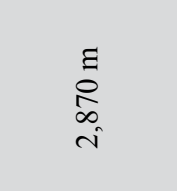 & $\begin{array}{l}\Xi \\
\stackrel{\Xi}{~} \\
\text { nे }\end{array}$ & $\begin{array}{l}\Xi \\
b \\
\vec{i} \\
a\end{array}$ & 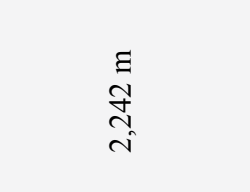 & $\begin{array}{l}\text { E } \\
\stackrel{0}{0} \\
\stackrel{0}{N}\end{array}$ \\
\hline$\sum_{\Leftrightarrow}^{\infty}$ & 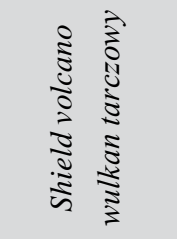 & 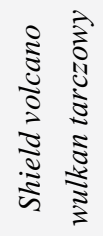 & 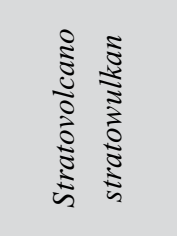 & 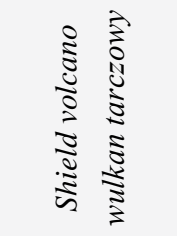 & 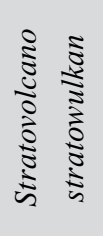 & 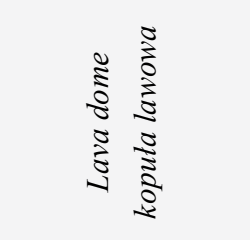 & 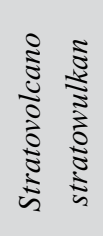 \\
\hline 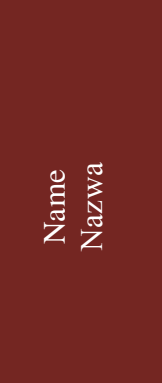 & 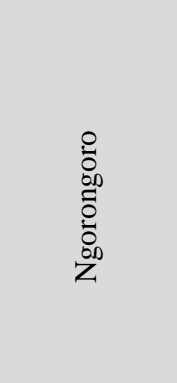 & 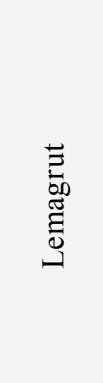 & 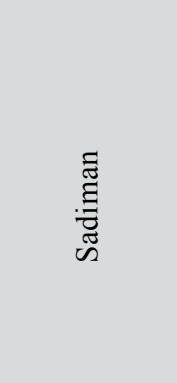 & $\begin{array}{l}\overline{\bar{\Xi}} \\
\overline{0} \\
\overline{0}\end{array}$ & 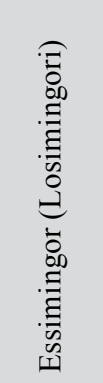 & 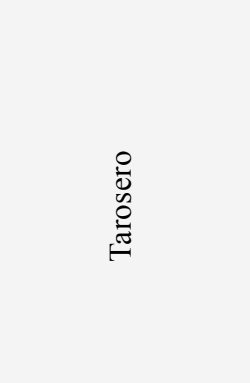 & $\begin{array}{l}\overline{\bar{E}} \\
\bar{\Xi} \\
\overline{0} \\
\bar{\Sigma}\end{array}$ \\
\hline$z_{z}^{\prime \prime}$ & $a$ & 우 & $=$ & $\approx$ & $m$ & $\exists$ & 느 \\
\hline
\end{tabular}




\begin{tabular}{|c|c|c|c|c|c|c|}
\hline 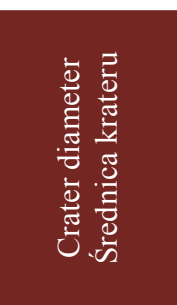 & 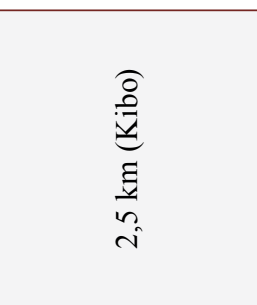 & 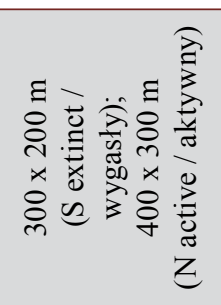 & 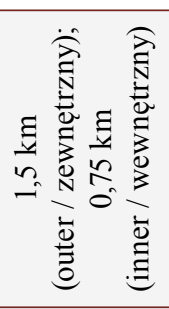 & | & | & $\frac{\Xi}{\sim}$ \\
\hline 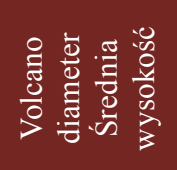 & $\begin{array}{l}\xi \\
\vdots \\
y \\
x \\
\infty \\
\infty\end{array}$ & $\frac{\Xi}{\beth}$ & $\frac{\Xi}{ \pm}$ & $\begin{array}{l}\frac{\Xi}{5} \\
6 \\
x \\
n \\
n \\
\end{array}$ & $\frac{\Xi}{\tilde{a}}$ & $\frac{\Xi}{\infty}$ \\
\hline 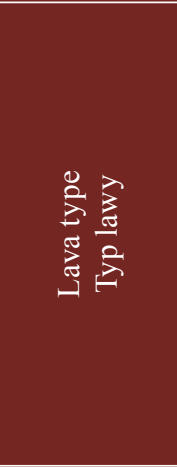 & 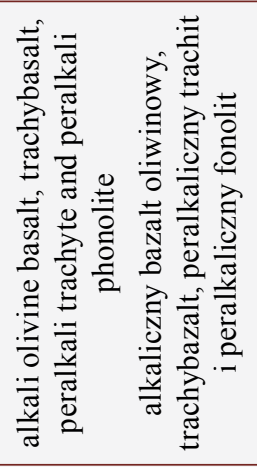 & 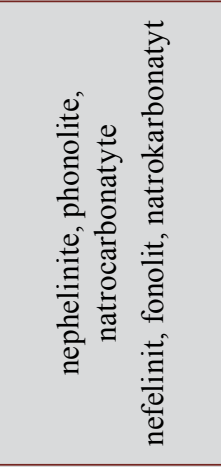 & 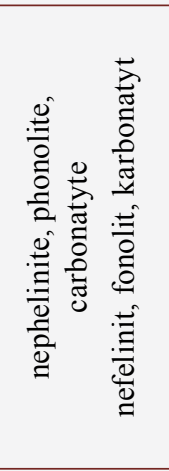 & 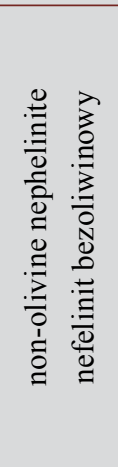 & 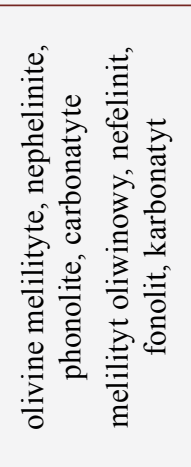 & 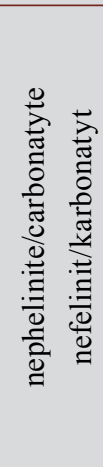 \\
\hline 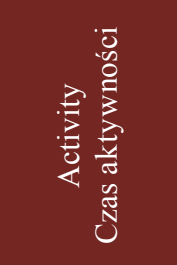 & 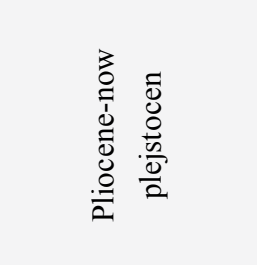 & 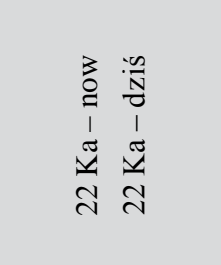 & 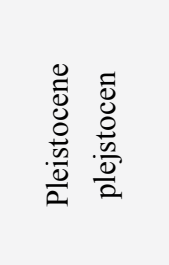 & 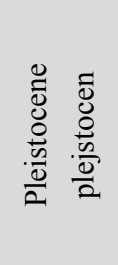 & 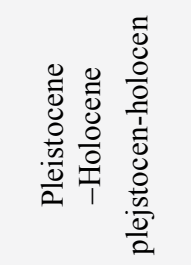 & 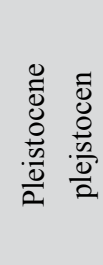 \\
\hline 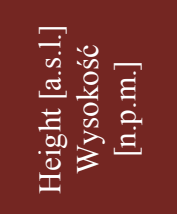 & 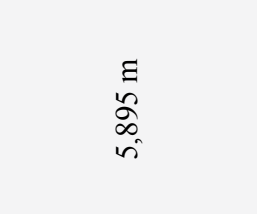 & $\begin{array}{l}\text { E } \\
\stackrel{2}{0} \\
0 \\
i\end{array}$ & 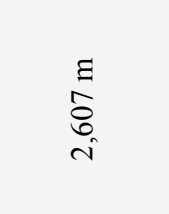 & $\begin{array}{l}\Xi \\
\stackrel{0}{0} \\
\stackrel{i}{i}\end{array}$ & $\begin{array}{l}\Xi \\
0 \\
0 \\
\swarrow \\
\sim \\
\sim\end{array}$ & 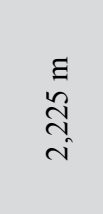 \\
\hline$\overbrace{\vec{\beta}}^{\infty}$ & 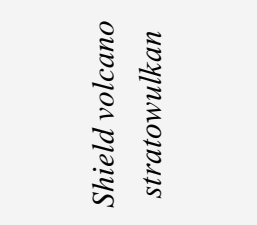 & 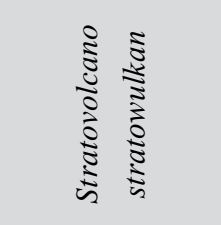 & 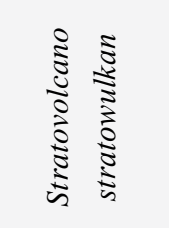 & 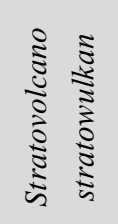 & 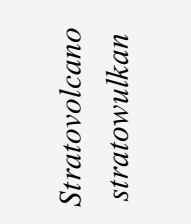 & 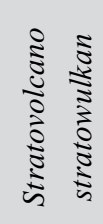 \\
\hline $\begin{array}{l}\text { 蛋 } \\
\text { 壳 } \\
\text { Z }\end{array}$ & 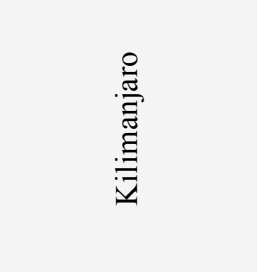 & 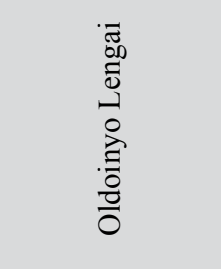 & 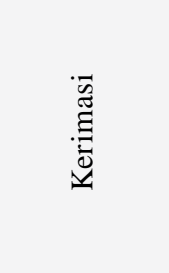 & 章 & $\sum_{\Sigma}^{\vec{D}}$ & 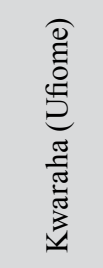 \\
\hline z & $\mathscr{\varphi}$ & 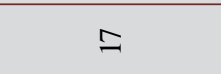 & 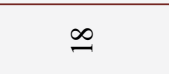 & 2 & ฉે & $\vec{N}$ \\
\hline \multicolumn{7}{|c|}{ nuz!̣ury[n } \\
\hline
\end{tabular}




\begin{tabular}{|c|c|c|c|c|c|}
\hline 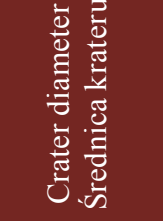 & $\frac{\Xi}{\sim}$ & 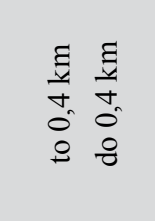 & | & 1 & 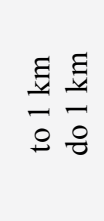 \\
\hline 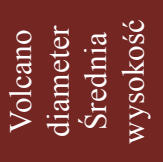 & 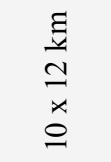 & 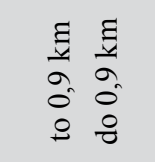 & | & 1 & 1 \\
\hline 总 & 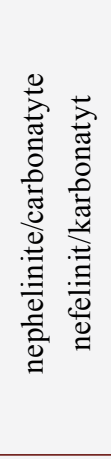 & 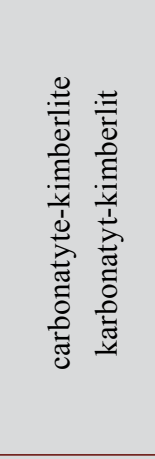 & 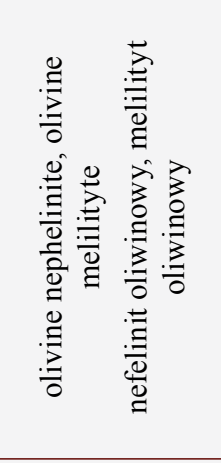 & 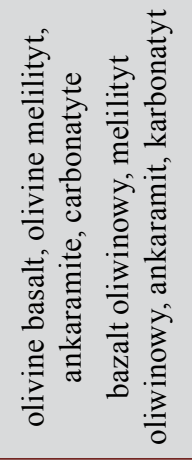 & 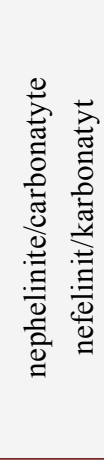 \\
\hline 离 & 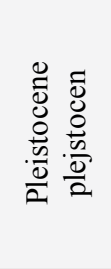 & 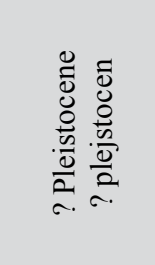 & 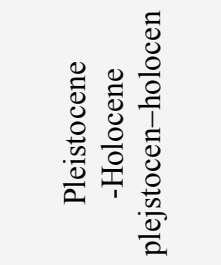 & 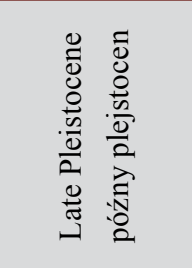 & 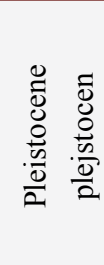 \\
\hline 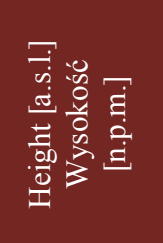 & 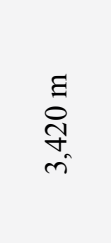 & 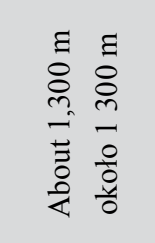 & 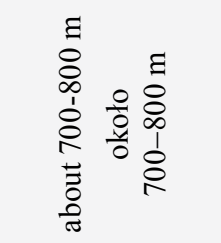 & 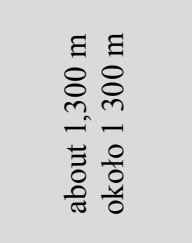 & 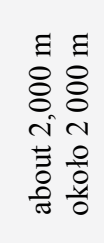 \\
\hline 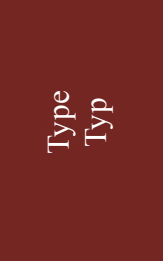 & 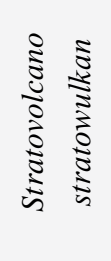 & 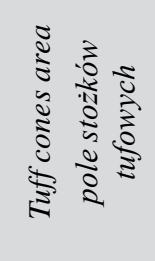 & 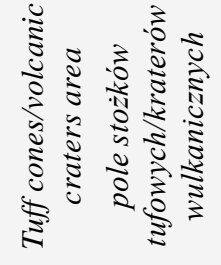 & 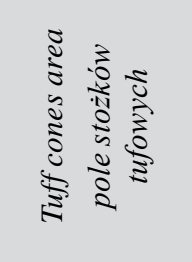 & 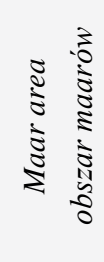 \\
\hline 莺 & 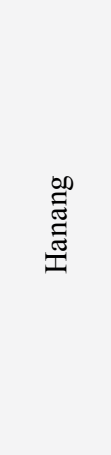 & 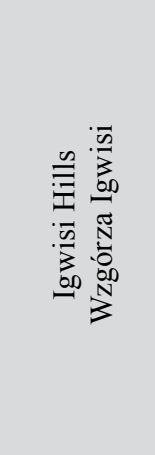 & 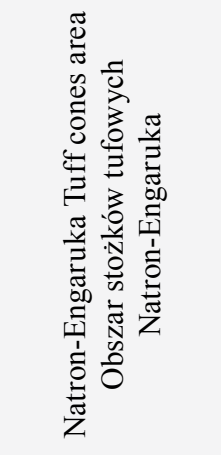 & 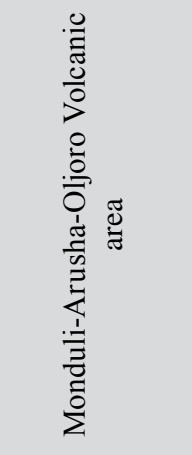 & 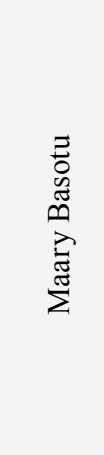 \\
\hline za & $\approx$ & $\tilde{\lambda}$ & $\stackrel{\Xi}{\sim}$ & $\stackrel{\mathscr{N}}{N}$ & $\ddot{\nu}$ \\
\hline \multicolumn{6}{|c|}{ 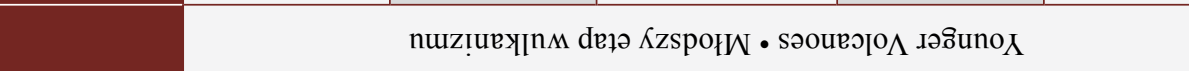 } \\
\hline
\end{tabular}


Tab. 2. Age of rocks from the Ngorongoro Crater - Wiek skał Krateru Ngorongoro

\begin{tabular}{|c|c|c|c|}
\hline $\begin{array}{l}\mathrm{No} \\
\mathrm{Nr}\end{array}$ & $\begin{array}{l}\text { Rock } \\
\text { Skała }\end{array}$ & $\begin{array}{c}\text { Age }[\mathrm{Ma}] \\
\text { Wiek [mln lat] }\end{array}$ & $\begin{array}{c}\text { Source } \\
\text { Źródło danych }\end{array}$ \\
\hline 1 & $\begin{array}{l}\text { Ignimbrite } \\
\text { Ignimbryt }\end{array}$ & $1.83 \pm 10.03$ & Manega 1993, vide Dawson 2008 \\
\hline 2 & $\begin{array}{l}\text { Ignimbrite } \\
\text { Ignimbryt }\end{array}$ & $1.98 \pm 0.032$ & Manega 1993, vide Dawson 2008 \\
\hline 3 & $\begin{array}{l}\text { Ignimbrite } \\
\text { Ignimbryt }\end{array}$ & $2.02 \pm 0.02$ & Manega 1993, vide Dawson 2008 \\
\hline 4 & $\begin{array}{l}\text { Trachite } \\
\text { Trachyt }\end{array}$ & $2.45 \pm 0.15$ & Grommé et al. 1970 \\
\hline 5 & $\begin{array}{l}\text { Plagioclase (tuff) } \\
\text { Plagioklaz (tuf) }\end{array}$ & $2.23 \pm 0.1$ & Grommé et al. 1970 \\
\hline 6 & $\begin{array}{l}\text { Plagioclase (tuff) } \\
\text { Plagioklaz (tuf) }\end{array}$ & $2.28 \pm 0.14$ & Grommé et al. 1970 \\
\hline 7 & $\begin{array}{l}\text { Plagioclase (tuff) } \\
\text { Plagioklaz (tuf) }\end{array}$ & $2.45 \pm 0.15$ & Grommé et al. 1970 \\
\hline 8 & $\begin{array}{l}\text { Plagioclase (tuff) } \\
\text { Plagioklaz (tuf) }\end{array}$ & $2.25 \pm 0.15$ & Grommé et al. 1970 \\
\hline 9 & $\begin{array}{l}\text { Plagioclase (tuff) } \\
\text { Plagioklaz (tuf) }\end{array}$ & $2.81 \pm 0.11$ & Grommé et al. 1970 \\
\hline 10 & $\begin{array}{c}\text { Olivine basalt } \\
\text { Bazalt oliwinowy }\end{array}$ & $3.7 \pm 0.8$ & Bagdasaryan et al. 1973 \\
\hline 11 & $\begin{array}{l}\text { Trachidacite } \\
\text { Trachydacyt }\end{array}$ & $2.25 \pm 0.02$ & Mollel et al. 2008 \\
\hline 12 & $\begin{array}{c}\text { Olivine basalt } \\
\text { Bazalt oliwinowy }\end{array}$ & $2.20 \pm 0.02$ & Mollel et al. 2008 \\
\hline 13 & $\begin{array}{l}\text { Tuff } \\
\text { Tuf }\end{array}$ & $2.23 \pm 0.08$ & Mollel et al. 2008 \\
\hline 14 & $\begin{array}{l}\text { Tuff } \\
\text { Tuf }\end{array}$ & $2.01 \pm 0.02$ & Mollel et al. 2008 \\
\hline
\end{tabular}




\section{Streszczenie}

\section{Krater Ngorongoro największą atrakcją geoturystyczną ryftu Gregory'ego (północna Tanzania, Afryka) - dziedzictwo geologiczne}

\section{Jerzy Żaba, Krzysztof Gaidzik}

\section{Wstęp}

Krater Ngorongoro corocznie jest odwiedzany przez setki tysięcy turystów ze wszystkich zakątków kuli ziemskiej. Przyciąga on i ujmuje przede wszystkim niewątpliwym bogactwem przyrody ożywionej (Żaba, Gaidzik 2011a) oraz unikalnością i magicznym pięknem krajobrazów (Fig. 1). W jego obrębie można obserwować wiele endemicznych, tudzież rzadkich gatunków roślin i zwierząt, często zagrożonych wyginięciem (np. nosorożca czarnego). Obecność na tym obszarze - niezmiernie egzotycznej dla Europejczyka - autochtonicznej ludności masajskiej oraz doniosłe archeologiczne odkrycia dokonane w pobliżu krateru, stanowiąc niewątliwe wartości kulturowe, dodatkowo podnoszą atrakcyjność tego obiektu. Ponadto Krater przyciąga również swą niezmiernie interesującą ewolucją geologiczną, ściśle związaną z aktywnością procesów zachodzących w obrębie ryftu Gregory'ego, stanowiącego segment wschodniego ramienia wschodnioafrykańskiego systemu ryftowego.

Krater Ngorongoro znajduje się w północnej Tanzanii, w prowincji Arusha, w pobliżu granicy z Kenią. Leży on na Wyżynie Kraterów, stanowiącej fragment Wyżyny Wschodnioafrykańskiej. Oprócz Ngorongoro na Wyżynie tej znajduje się wiele innych, w zdecydowanej większości obecnie wygasłych, wulkanów tarczowych. Część z nich (np. Empakai, Olmoti) ma również formę kalder wulkanicznych, jednakże o znacznie mniejszych rozmiarach. Z geologicznego punktu widzenia krater Ngorongoro jest usytuowany w obrębie ryftu Gregory'ego, który stanowi południowy segment wschodnioafrykańskiego systemu ryftowego. Stanowi on największą na Ziemi - niezniszczoną i niezalaną wodą - kalderę zapadliskową wygasłego wulkanu tarczowego, której ściany wznoszą się na wysokość kilkuset metrów (500$600 \mathrm{~m}$ ) ponad jej dno oraz niemalże 1,5 km powyżej dna występującej na tym obszarze doliny ryftowej. Centrum erupcyjne zaczęło kształtować się w tym regionie w pliocenie, czyli zaledwie niecałe $3 \mathrm{mln}$ lat temu i było aktywne przez niemal ćwierć miliona lat.

Niniejsza praca jest drugą z serii trzech artykułów poświęconych kraterowi Ngorongoro jako największej atrakcji geoturystycznej ryftu Gregory'ego i jednej z największych w całej Afryce Wschodniej. Pierwsza z nich została poświęcona uwarunkowaniom geograficznym z wyłączeniem problematyki geologicznej krateru (Żaba, Gaidzik 2011a). Natomiast trzecia obejmuje zagadnienia związane z zagospodarowaniem turystycznym tego obszaru, a także z wynikającymi stąd zagrożeniami zarówno dla świata przyrody ożywionej, jak i nieożywionej (Żaba, Gaidzik 2011b).

\section{Ryft Gregory'ego na tle wschodnioafrykańskiego} systemu ryftowego

Krater Ngorongoro jest położony w obrębie ryftu Gregory’ego stanowiącego południowy segment wschodniego ramienia wschodnioafrykańskiego systemu ryftowego, rozciągającego się południkowo od wybrzeży Morza Czerwonego i Zatoki Adeńskiej na północy aż po wybrzeża Oceanu Indyjskiego w Mozambiku (Fig. 2). Jego łączna długość wynosi około $6400 \mathrm{~km}$. Dzieli się on na dwa ramiona: ryft wschodni i ryft zachodni, pomiędzy którymi znajduje się Jezioro Wiktorii.

Zachodnie ramię (ryft zachodni) ciągnie się od górnego biegu Nilu Alberta i Nilu Górskiego, poprzez wielkie jeziora afrykańskie: Alberta, Edwarda, Kiwu, Tanganika, Rukua i Malawi (Niasa), aż po miejscowość Beira w Mozambiku, leżącą już na wybrzeżu Oceanu Indyjskiego.

Wschodnia Dolina Ryftowa rozciąga się od cieśniny Bab-el-Mandeb (leżącej u zbiegu ryftów Morza Czerwonego i Zatoki Adeńskiej), poprzez jeziora: Turkana (Rudolfa), Natron i Manyara oraz rzekę Pangani, po wybrzeża Oceanu Indyjskiego. Segment tej doliny znajdujący się na obszarach Kenii i Tanzanii nosi nazwę ryftu Gregory'ego.

Odpowiednikiem morfologicznym wschodnioafrykańskiego systemu ryftowego są Wielkie Rowy Afrykańskie. Szerokość dolin ryftowych w tym systemie waha się zazwyczaj w granicach od 40 do $60 \mathrm{~km}$, natomiast ich bardzo strome zbocza, mające charakter skarp uskokowych, nierzadko wznoszą się na wysokość $900 \mathrm{~m}$, a nawet 2700 m (np. urwisko Mau w Kenii) ponad dno rowu.

Pod względem tektonicznym wschodnioafrykański system ryftowy stanowi jedno z ramion trójzłącza Afaru, związanego $\mathrm{z}$ ewolucją znajdującej się na tym obszarze plamy gorąca. Jej rozwój - ściśle powiązany z aktywnością znajdującego się poniżej pióropusza płaszcza - trwa od późnego mezozoiku do czasów współczesnych. W miocenie (około $20 \mathrm{mln}$ lat temu) procesy ryftogenezy doprowadziły do rozerwania skorupy kontynentu Gondwany i powstania ryftów: Morza Czerwonego, Zatoki Adeńskiej i wschodnioafrykańskiego. Kąty pomiędzy poszczególnymi ramionami tego trójzłącza (punktu potrójnego Afaru) wynoszą około $120^{\circ}$. Bardziej intensywny rozwój ryftów Morza Czerwonego i Zatoki Adeńskiej doprowadził do rozpadu skorupy kontynentalnej i powstania $\mathrm{w}$ ich strefach osiowych litosfery oceanicznej. Ryfty te stanowią obecnie naturalną, tektoniczną granicę między płytami litosfery - afrykańską i arabską. Znacznie wolniejszy rozwój wschodnioafrykańskiego systemu ryftowego spowodował, iż do tej pory w jego podłożu zachowała się litosfera kontynentalna. Ma on nadal charakter ryftu wewnątrzkontynentalnego. Stanowi ramię porzucone trójzłącza, podobnie jak Rów Benue znajdujący się w Afryce Zachodniej nad Zatoką Gwinejską. Z czasem ryft ten przekształci się prawdopodobnie w aulakogen (Żaba 2005).

Wschodnioafrykański system ryftowy ma bardzo złożoną budowę. Oprócz podziału na dwa subpołudnikowo przebiegające ramiona jest on również rozczłonowany - wzdłuż rozciągłości - na segmenty poprzemieszczane uskokami poprzecznymi bądź kulisowymi. Niektóre odcinki systemu ryftowego składają się z naprzemiennie rozmieszczonych półrowów lub asymetrycznych rowów (o przeciwnie skierowanej asymetrii). Uskoki ograniczające półrowy mają 
w planie kształt łukowaty, co ściśle wiąże się z ich listryczną naturą. Wewnątrz ryftów zaznaczają się liczne wtórne zręby (Żaba 2005). Ramiona ryftów są przeważnie wyraźnie podniesione względem centralnej doliny, przyjmując formę zrębów lub półzrębów. Wypiętrzanie wiszących skrzydeł rowów wschodnioafrykańskich zachodziło głównie w późnym neogenie (Burke et al. 1981) oraz w czwartorzędzie (Barker et al. 1988). Główny etap uskokowania ryftowego w obrębie ryftu Gregory'ego, który nadał temu obszarowi jego obecny charakter, miał miejsce pomiędzy 1,26 a 1,0 mln lat temu (Foster et al. 1997).

Wschodnioafrykański system ryftowy należy do obszarów sejsmicznych o intensywnej aktywności wulkanicznej. Szczególnie silne i częste trzęsienia ziemi mają miejsce w obrębie ramienia zachodniego. Na obszarze ryftu Gregory'ego, stanowiącego segment ramienia wschodniego, trzęsienia ziemi są znacznie rzadsze i o mniejszej magnitudzie. Jedynie sporadycznie osiągają 5 stopni w skali Mercallego.

Obszar ryftu Gregory'ego dwukrotnie doświadczał wzmożonej aktywności wulkanicznej. Starszy etap wulkaniczny miał miejsce ponad 1,2 mln lat temu, jeszcze przed głównym uskokowaniem. Młodszy rozpoczął się około milion lat temu i trwa do dnia dzisiejszego (Mollel et al. 2008). Świadectwem ciągle żywych procesów geologicznych na tym obszarze są czynne wulkany ryftu Gregory'ego: Meru i Oldoinyo Lengai. Meru, położony około $130 \mathrm{~km}$ na wschód od Ngorongoro (Fig. 3), wznosząc się na wysokość 4565 m n.p.m., stanowi najwyższy czynny wulkan kontynentalnej Afryki. Jego ostatnia erupcja miała miejsce w 1910 roku (Tab. 1). Oldoinyo Lengai, znajdujący się na obszarze Wyżyny Kraterów około $65 \mathrm{~km}$ na północny wschód od Ngorongoro (Fig. 3), jest jedynym czynnym wulkanem karbonatytowym na kuli ziemskiej (Tab. 1). Jego ostatnie erupcje miały miejsce pod koniec 2007 i na początku 2008 roku. Czynnymi wulkanami leżącymi w strefie ryftu zachodniego są: Nyiragongo (3470 m n.p.m.) i Nyamuragira (3056 m n.p.m.). Znajdują się one na terytorium Demokratycznej Republiki Konga. Ostatnia erupcja wulkanu Nyiragongo miała miejsce w 1982 r., natomiast Nyamuragira - w 1977 r.

\section{Historia oraz dziedzictwo geologiczne}

\section{krateru Ngorongoro}

Powstanie wulkanu Ngorongoro jest ściśle genetycznie powiązane $\mathrm{z}$ ewolucją wschodnioafrykańskiego systemu ryftowego, a w szczególności tanzańskiej części ryftu Gregory’ego. Centrum erupcyjne na tym obszarze zaczęło się kształtować w pliocenie, ponad $2 \mathrm{mln}$ lat temu i było aktywne przez niemal ćwierć miliona lat (Mollel et al. 2008). Należy ono do rozległych wulkanów tarczowych Wyżyny Kraterów, pochodzących z wczesnego etapu wulkanizmu (Tab. 1).

Pomimo iż wiek najstarszych skał budujących wulkan Ngorongoro jest szacowany na mniej niż 2,5 mln lat, aby prześledzić historię jego powstania należy również poznać ewolucję obszaru, w obrębie którego on występuje. Ta rozpoczęła się w zamierzchłej przeszłości, prawdopodobnie ponad 2 mld lat temu.

\section{Powstanie skal krystalicznego podłoża}

Historia geologiczna obszaru, objętego obecnie przez kalderę wulkanu Ngorongoro rozpoczęła się prawdopodobnie ponad 2 mld lat temu, od depozycji materiałów okruchowych, z których powstały najstarsze skały osadowe, reprezentowane głównie przez piaskowce, mułowce i iłowce (Fig. 4). Skały te podczas ruchów tektonicznych uległy sfałdowaniu i zmetamorfizowaniu w związku ze wzrastającą temperaturą i ciśnieniem, w warunkach metamorfizmu regionalnego, przechodząc w kwarcyty, gnejsy i łupki metamorficzne. Na przeobrażenia o charakterze regionalnym nałożyły się zmiany kontaktowe (metamorfizm termiczny i metasomatyczny), związane $z$ intruzjami granitoidowymi, do jakich dochodziło na tym obszarze. Intrudująca magma dostarczała wiele nowych związków chemicznych, pod wpływem których dochodziło do zmian składu chemicznego i mineralnego wcześniej ukształtowanych skał (Fig. 4; Pickering 1994).

Najstarszy etap ewolucji tego obszaru zakończył się gwałtownymi ruchami skorupy ziemskiej, w wyniku których sfałdowane i zmetamorfizowane skały uległy wypiętrzeniu. Wzdłuż granicy gnejsów i granitów rozwinęła się wtedy walna strefa ścinania, w obrębie której skały uległy skruszeniu, zmieleniu i przemieszczeniu (Pickering 1994). W ten sposób - w warunkach metamorfizmu dyslokacyjnego - utworzyły się skały kataklastyczne reprezentowane przez mylonity, a gdzieniegdzie też kataklazyty i brekcje tektoniczne.

\section{Denudacja}

Procesy intensywnej denudacji zachodziły na tym obszarze od prekambru po miocen. Jest to najdłuższy etap w historii geologicznej krateru Ngorongoro oraz jedyny okres podczas którego tak wyraźnie dominowały procesy generowane przez czynniki egzogeniczne. W tym tak długim czasie obszar ten nie podlegał żadnym znaczącym ruchom tektonicznym. Wcześniej wypiętrzone skały ulegały intensywnej denudacji prowadzącej do niszczenia i wyrównywania terenu. Dodatkowym czynnikiem zwiększającym podatność skał na denudację był brak pokrywy roślinnej. Utwory te ulegały przede wszystkim takim procesom jak wietrzenie fizyczne i chemiczne, ruchy masowe, erozja rzeczna oraz korazja i deflacja. Początkowo krajobraz przypominał najprawdopodobniej obecnie obserwowane młode pasma górskie utworzone w orogenezie alpejskiej (Fig. 4). Dominowały zatem turnie o stromych zarysach, ostre, skaliste granie oraz głębokie V-kształtne doliny rzeczne. U podnóża ścian skalnych były usypywane stożki piargowe. Około $400 \mathrm{mln}$ lat temu na obszarze tym pojawiła się roślinność, która stanowiła pewną ochronę przed niszczącym wpływem erozji. Jednocześnie jednak wskutek rozwoju wietrzenia biogenicznego powodowała ona jeszcze większą intensywność procesów dezintegrujących skały.

Długotrwała działalność procesów denudacyjnych na tym obszarze doprowadziła do zniszczenia stromych, skalistych gór o charakterze alpejskim i ukształtowania się nieznacznie pofalowanej powierzchni o charakterze prawierówni, czyli tzw. penepleny (Fig. 4). Dodatkowo erozja ta doprowadziła do wypreparowania i odsłonięcia na powierzchni najbardziej odpornych na działanie niszczących procesów erozyjnych prekambryjskich skał krystalicznych. W ten sposób ukształtowane ostańce denudacyjne do dziś zaznaczają się w terenie w niezmienionej formie. Należą do nich przede wszystkim, zbudowane $\mathrm{z}$ prekambryjskich krystalicznych skał magmowych i metamorficznych, wzgórza Doinyoogol oraz izolowane wzgórza: Lemuta, Loirujruj, Naibor i Naibardad (Pickering 1994). 


\section{Pierwszy etap ryftogenezy}

Około $20 \mathrm{mln}$ lat temu $\mathrm{w}$ miocenie nastąpił intensywny rozwój procesów ryftogenezy, prowadzących m.in. do powstania Wyżyny Kraterów oraz wulkanu, a następnie kaldery Ngorongoro. Przejawem tych procesów związanych z aktywnością pióropusza płaszcza było utworzenie na tym obszarze potężnego uskoku, który obecnie przebiega wzdłuż NW brzegu jeziora Eyasi, a następnie zmieniając kierunek na południkowy zmierza ku północy, przecinając wzgórza Doinyoogol (Fig. 4, 5). Skrzydło wschodnie tego uskoku uległo obniżeniu o około 1000-2000 m względem skrzydła zachodniego. W wyniku jego aktywności rozwinęła się potężna ryftowa skarpa uskokowa. Jednocześnie w części południowo-zachodniej regionu, fragment tego obszaru ograniczony przez uskok główny oraz dwa uskoki niższego rzędu został wydźwignięty, tworząc blok Loirujruj (Fig. 4; Pickering 1994).

\section{Starszy etap wulkanizmu}

\section{i tworzenie się Wyżyny Kraterów}

Najstarszy wulkanizm na tym obszarze był ograniczony do terenów położonych na wschód od uskoku głównego powstałego w pierwszym etapie ryftogenezy (Fig. 4). Był on reprezentowany przez lawy obojętne i zasadowe wydostające się na powierzchnię poprzez wydłużone szczeliny, otwarte podczas uskokowania. Charakteryzowały się one niewielką lepkością i dlatego mogły rozprzestrzeniać się na znaczne odległości. Wylewy tych law utworzyły rozległe pokrywy bazaltowe (tzw. trapy bazaltowe) na obszarze wschodniego, obniżonego skrzydła ryftu, sięgające aż do Kilimandżaro. Ich ekspansja w kierunku zachodnim była blokowana przez główną skarpę ryftową (Fig. 4), która w wyniku zalewania od dołu przez kolejne potoki lawowe i erodowania od góry przez rzeki (np. Karian i Togom) ulegała stopniowemu wyrównywaniu i zanikaniu (Pickering 1994).

Ponad 2 mln lat temu, w pliocenie, dotychczasowy wulkanizm szczelinowy uległ transformacji w wulkanizm kominowy. Do dziś na tym obszarze zachowało się siedem takich kominów - centrów erupcyjnych. Z każdego centrum lawa wypływała we wszystkich kierunkach, tworząc rozległe stożki wulkanów tarczowych, które z czasem - w miarę rozrastania - łączyły się ze sobą. Powstały wówczas bardzo rozległe wulkany tarczowe (głównie bazaltowo-trachyandezytowe) Wyżyny Kraterów takie jak Empakai, Olmoti, Loolmalasin, Ngorongoro, Lemagrut, Sadiman, Oldeani (Tab. 1, Fig. 5). Ponadto - poza obszarem Wyżyny - utworzyły się stożki wulkaniczne: Shombole, Oldoinyo Sambu, Mosonik, Gelai oraz Ketumbeine. Z okresem tym związane jest również kształtowanie się wielkich centrów erupcyjnych: Essimingor, Tarosero, Monduli i Kilimandżaro (Tab. 1, Fig. 5; Dawson 2008).

Wraz z upływem czasu lawa stawała się coraz mniej lepka, a zatem mniej ruchliwa, a wulkany zaczęły wykazywać aktywność eksplozyjną. Prawdopodobnie najwcześniejsza działalność wulkaniczna tego typu została zapoczątkowana w centrum Ngorongoro. Najnowsze datowania najstarszych skał wulkanicznych z tego wulkanu wskazują, iż był on aktywny przez prawie ćwierć miliona lat: od 2,25 $\pm 0,02$ do 2,01 mln lat temu. Dawniej uważano, iż rozpoczęcie aktywności tego wulkanu miało miejsce około 2,5 mln lat temu (Tab. 2; Mollel et al. 2008). Rosnące w tym okresie wulkany były znacznie wyższe niż obecnie. Wulkan Ngorongoro miał wtedy najprawdopodobniej wysokość około 4500-5000 m n.p.m., a zatem wznosił się prawie $3000 \mathrm{~m}$ powyżej obecnego obrzeża kaldery. Jednak potężna erupcja wulkaniczna, która zaszła w tym okresie, zniszczyła część szczytową wulkanu Ngorongoro oraz zachodnie stoki wulkanu Oldeani. Mniejsze eksplozje wulkaniczne doprowadziły do powstania dwóch kalder w obrębie wulkanu Losirua (Pickering 1994).

Pod koniec tego etapu lokalizacja aktywności wulkanicznej po wschodniej stronie uskoku głównego uległa radykalnej zmianie, a wylewy bazaltoidów niemal całkowicie wypełniły starą dolinę ryftową.

\section{Drugi etap ryftogenezy -}

\section{powstanie Krateru Ngorongoro}

Drugi etap ryftogenezy ściśle wiąże się z uskokowaniem prowadzącym do ukształtowania się doliny ryftu Gregory'ego. Procesy związane z tym etapem zachodziły około 1,261,0 mln lat temu (Mollel et al. 2008). Dolina ryftowa utworzyła się wzdłuż nowo powstałego uskoku głównego normalno-zrzutowego o przebiegu południkowym, znajdującego się wzdłuż wschodniej granicy Wyżyny Kraterów (Fig. 4). Jego powstanie doprowadziło do częściowego zniszczenia wschodnich stożków wulkanicznych na tym obszarze. Podobnie jak podczas pierwszego etapu ryftogenezy względnemu obniżeniu podlegało skrzydło wschodnie, zaś podniesieniu - skrzydło zachodnie. Właśnie na nim znajdowały się liczne stożki wulkaniczne, w tym także wulkanu Ngorongoro. O amplitudzie zrzutu tego uskoku świadczą między innymi obecne deniwelacje terenu, które często znacznie przekraczają $1000 \mathrm{~m}$.

W etapie tym wokół centrum erupcyjnego Ngorongoro utworzyły się bardzo liczne spękania i uskoki koncentryczne. Stanowiły one odbicie procesów zachodzących w głębi ziemi. Intensywna działalność wulkaniczna trwająca przez ponad 200 tysięcy lat, doprowadziła do wyczerpania się zbiornika magmy pod wulkanem. Następstwem takiej sytuacji było zapadnięcie się centralnej części wulkanu i powstanie potężnej, zapadliskowej kaldery wulkanicznej, znanej obecnie jako Krater Ngorongoro. Analogiczne procesy, lecz na znacznie mniejszą skalę, objęły wulkany Olmoti i Empakai, gdzie również utworzyły się kaldery zapadliskowe (krater Olmoti i krater Empakai; Fig. 4).

Potężne kolapsy w obrębie Wyżyny Kraterów doprowadziły do powstania wielu pomniejszych uskoków (niższego rzędu): 1 - ograniczających Bulbul od zachodu, 2 - tnących w poprzek szczyt Losirua oraz 3 - warunkujących powstanie doliny pomiędzy szczytem Losirua a wschodnim pasmem Loolmalasin. Ponadto tego typu struktury utworzyły się na zboczach wielu wulkanów znajdujących się na Wyżynie Kraterów takich jak Ngorongoro, Makarut i Olmoti. Niewielkie uskoki, powstałe w tym samym czasie, występują również w rejonie Tepess oraz w rejonie Kilim-Tembo (Pickering 1994).

W powstałej podczas drugiego etapu ryftogenezy dolinie ryftu Gregory'ego utworzyły się najważniejsze zbiorniki wodne tego rejonu takie jak jeziora Manyara i Natron z basenami Engaruka i Olmkoko. Natomiast w obrębie Wyżyny Kraterów powstały jeziora: Ngorongoro, Malanja, Bulbul i Empakai (Pickering 1994). 


\section{Młodszy etap wulkanizmu}

Młodszy etap wulkaniczny wyróżniający się aktywnością eksplozywną został zapoczątkowany około $1 \mathrm{mln}$ lat temu, już po utworzeniu się doliny ryftu Gregory'ego oraz potężnych kalder wulkanicznych. Etap ten trwa do czasów współczesnych. W tym okresie powstały najważniejsze stratowulkany tego obszaru: Meru, Monduli, Oldoinyo Lengai, Kerimasi, Burko i Kwaraha, a także mniejsze stożki tufowe i kratery (Tab. 1, Fig. 4, 6). Wulkany te są zbudowane głównie z bezoliwinowych nefelinitów i fonolitów. Etap ten charakteryzował się też karbonatytowymi erupcjami wulkanów: Oldoinyo Lengai, Kerimasi, Kwaraha i Hanang (Tab. 1), położonymi w obrębie lub na wschód od najważniejszych uskoków ograniczających (Foster et al. 1997).

Potężne erupcje eksplozywne wulkanu Kerimasi (2607 m n.p.m.; Tab. 1; Dawson 2008) spowodowały pokrycie znacznych obszarów popiołami i pyłami wulkanicznymi zawierającymi znaczne ilości kalcytu. Wapienne tufy, stanowiące ślad tej aktywności, występują między innymi: 1 - w dolinie ryftu Gregory'ego wokół Kerimasi i Bulbul, 2 - w rejonie Balbal, 3 - w zachodniej części Ngorongoro (prawie całkowicie wypełniły krater wzgórza Engitati), 4 - w wąwozie Olduvai (wypełniają wąwóz Olduvai) oraz 5 - na znacznych obszarach równin Salei i Serengeti, zwłaszcza u podnóża wzgórz Doinyoogol, gdzie osiągają miąższość zdecydowanie przekraczającą $100 \mathrm{~m}$. Wapienne tufy pochodzące z obecnie wygasłego wulkanu Kerimasi tworzą pylaste ziemie na równinach Serengeti i Salei (Pickering 1994).

Podczas gdy wulkan Kerimasi kończył swoją działalność, aktywność rozpoczął nowy, leżący około 11,3 km na północ, wulkan Oldoinyo Lengai (2890 m n.p.m.; Tab. 1; Dawson 2008). Intensywne erupcje tego stratowulkanu w szybkim czasie spowodowały utworzenie się symetrycznego stożka zbudowanego z aglomeratów i tufów zawierających lawy. Stanowi on jedyny na kuli ziemskiej czynny wulkan karbonatytowy (Pickering 1994; Dawson 2008).

Ślady niewielkiej aktywności wulkanicznej (o charakterze eksplozywnym) tego etapu zaznaczyły się też wewnątrz nowo powstałej kaldery Ngorongoro, w postaci niewielkich, kopczykowatych wzniesień zbudowanych z materiałów piroklastycznych. Formy te są rozmieszczone na obrzeżach dna kaldery, u podnóża stromo nachylonych jej ścian (Pickering 1994). Przykładem tej działalności wulkanu jest wzgórze Engitati położone wewnątrz kaldery Ngorongoro, zbudowane z materiałów piroklastycznych reprezentowanych przez popioły, pyły i tufy wulkaniczne (scoria) oraz aglomeraty. Szczytowa część tego wzgórza uległa w okresie późniejszym częściowemu zniszczeniu w wyniku gwałtownej eksplozji wulkanicznej. Utworzył się tam płytki rozległy krater, przez co forma ta upodobniła się do spodka.

Charakterystyczne, niewielkie wzniesienia tworzyły się też w innych rejonach Wyżyny Kraterów (np. w rejonie Melenda i na zboczach wulkanu Oldeani) oraz doliny ryftu Gregory'ego. Formy te - zbudowane z lawy - wykazują ścisły związek ze skarpami niewielkich uskoków, wzdłuż których koncentrowały się w owym czasie erupcje efuzywne.

Pod koniec tego etapu zarówno skarpy uskokowe, jak i zbocza stożków wulkanicznych występujących na obszarze
Wyżyny Wulkanów były erodowane oraz intensywnie rozcinane przez stałe i okresowe cieki, co prowadziło do kształtowania się licznych dolin rzecznych i wąwozów. U ich ujść często tworzyły się stożki napływowe utworzone z gruboklastycznych osadów. Drobniejszy materiał był wynoszony na większe odległości i deponowany w różnych obniżeniach terenu. Powodowało to między innymi zasypywanie i zmniejszanie rozmiarów (obecnie obserwowanych) większości jezior takich jak Eyasi, Manyara oraz Natron (Pickering 1994).

\section{Skały krateru Ngorongoro i okolicy}

Krater Ngorongoro jest zbudowany ze stosunkowo młodych skał wulkanicznych, z których najstarsze utworzyły się w pliocenie, czyli około $2 \mathrm{mln}$ lat temu (Mollel et al. 2008). Są one reprezentowane przede wszystkim przez lawy bazaltoidowe o składzie oliwinowych bazaltów, trachybazaltów i trachyandezytów (Fig. 7, 8, 9, 10, 11). Natomiast wśród produktów najmłodszych erupcji dominują ignimbryty (Tab. 2; por. Dawson 2008). W Kraterze Ngorongoro stwierdzono też występowanie innych skał wulkanicznych zidentyfikowanych jako hawaity (James 1966 vide Dawson 2008), bazanity, tefryty, fonotefryty (fonolitowe tefryty) oraz mugearyty (Wood 1968 vide Dawson 2008).

Według starszych danych aktywność wulkaniczna Ngorongoro obejmowała okres od 2,5 do około 2 mln lat temu (Tab. 2; Grommé et al. 1970). Najnowsze datowania izochronowe ${ }^{40} \mathrm{Ar} /{ }^{39} \mathrm{Ar}$ nie potwierdziły w całości wcześniej uzyskanych wyników (Mollel et al. 2008). Zgodnie z nimi wulkan Ngorongoro był aktywny jedynie przez ćwierć miliona lat, w przedziale wiekowym od 2,25 do około $2 \mathrm{mln}$ lat temu.

Niemal pełny profil litostratygraficzny skał budujących krater Ngorongoro można obserwować między innymi przy drodze wyjazdowej z krateru znanej pod nazwą Lerai (Fig. 12).

Znaczna część krateru Ngorongoro jest najprawdopodobniej podścielona przez tufy. Na dnie kaldery znajduje się też wiele niewielkich wzniesień (stożków) zbudowanych z materiałów i skał piroklastycznych. Jednym z nich jest wzgórze Engitati, w obrębie którego stwierdzono występowanie bazaltów odznaczających się charakterystyczną teksturą świadczącą, iż powstały one w wyniku podwodnych erupcji (Pickering 1965, vide Dawson 2008).

Na południowych i wschodnich brzegach słonego jeziora Makat, położonego wewnątrz kaldery wulkanu Ngorongoro, występują gliny jeziorne, wapienie margliste i tufy, których wiek - określony metodą ${ }^{14} \mathrm{C}$ - waha się od $27990 \pm 500$ do $24400 \pm 690$ tys. lat (Hay 1976).

W podłożu wulkanu Ngorongoro występują stare skały krystaliczne. Można je obserwować w obrębie wzgórz Doinyoogol leżących kilkanaście kilometrów na północ i północny-zachód od krateru. Szczytowe partie tych wzgórz są zbudowane z prekambryjskich, białych i czerwonych kwarcytów, poniżej których występują gnejsy i łupki łyszczykowe. Prekambryjskie skały metamorficzne odsłaniają się też na południowy zachód od krateru, w skarpie nad jeziorem Eyasi, leżącym u podnóża gór Loirujruj, a także budują znaczną część osamotnionej góry na obszarze Lemuta. Natomiast skały plutoniczne, reprezentowane przez granity, występują w obrębie bloku Loirujruj (Fig. 3). 


\section{Podsumowanie}

Krater Ngorongoro odznacza się wielkimi, unikalnymi w skali światowej, walorami przyrodniczymi (w tym też geologicznymi), a co za tym idzie - wyjątkowym potencjałem geoturystycznym (Żaba, Gaidzik 2011b). Do głównych, geologicznych walorów tego obszaru należą bardzo różnorodne, licznie reprezentowane formy wulkaniczne, wśród których na pierwsze miejsce wysuwa się potężna, największa na Ziemi (niezniszczona i niezalana wodą) kaldera wulkanu Ngorongoro. Wiążą się z nią niepowtarzalne krajobrazy, a co za tym idzie - estetyczne przeżycia. W obrębie kaldery występują liczne słone i słodkie jeziora oraz stożki tufowe mniejszych wulkanów eksplozywnych. Spotkać można tam bardzo wiele różnych skał wulkanicznych i piroklastycznych przyjmujących różne formy geologiczne i morfologiczne. Kaldera Ngorongoro występuje w towarzystwie innych wulkanów tarczowych oraz stratowulkanów, z których wiele wykazuje różne przejawy aktywności wulkanicznej. W pobliżu znajduje się jedyny na Ziemi aktywny wulkan karbonatytowy oraz przebiega krawędź (o charakterze skarpy uskokowej) potężnej doliny ryftowej stanowiącej segment największego na Ziemi systemu ryftów kontynentalnych. Zachodzące tu procesy mają fundamentalne znaczenie dla rozwoju skorupy ziemskiej. Obszar ten poza walorami estetycznymi dostarczającymi niezapomnianych wrażeń i emocji odznaczają się też wyjątkowo dużymi walorami geoedukacyjnymi.

Uznając wyjątkową atrakcyjność krateru Ngorongoro, w 1959 roku nadano temu obiektowi i obszarom przyległym status Obszaru Chronionego Ngorongoro (NCA). Został on również wpisany na Listę Światowego Dziedzictwa Kulturalnego i Przyrodniczego UNESCO, początkowo z uwagi na jego walory przyrodnicze, a następnie - z powodu doniosłości dokonanych tam odkryć archeologicznych - w 2010 roku obszar ten został przemianowany na obiekt mieszany.

\section{References (Literatura):}

Bagdasaryan, G., Gerasimovskiy, V., Polyakov, A., Gukasyan, R., Vernadskiy, V., 1973. Age of volcanic rocks in the rift zones of East Africa. Geochemistry International, 10: 66-71.

Barker, B.H., Mitchell, J.G., Williams, A.A.J., 1988. Stratigraphic geochronology and volcano-tectonic evolution of the Kedong-Naivasha-Kinangop region, Gregory Rift Valey, Kenya. Journal of the Geological Society, London, 145: 107-116.

Burke, K.C., Kidd, W.S.F., Turcotte, D.L., Dewey, J.F., Mouginis-Mark, P.J., Parmentier, E.M., Șengör, A.M., Tapponnier, P.E., 1981. Tectonics of basaltic volcanism. In: Basaltic volcanism on the terrestrial planets (Basaltic Volcanism Study Project). Pergamon, New York: 803-898.

Dawson, J.B., 2008. The Gregory Rift Valley and Neogene-Recent Volcanoes of Northern Tanzania. Geological Society, London, $102 \mathrm{pp}$.

Foster, A., Ebinger, C., Mbede, E. \& Rex, D., 1997. Tectonic development of the northern Tanzanian sector of the East African Rift System. Journal of the Geological Society, 154: 689-700.

Grommé, C., Reilly, T., Mussett, A.I, Hay, R., 1970. Tectonic development of the northern sector of the East African Rift System. Journal of the Geological Society, London, 126: 689-700.

Hay, R.L., 1976. Geology of the Olduvai Gorge. University of California Press, Berkeley, 203 pp.
James D.E., 1966. The carbonatites of Tanganyika: a phase of continentaltype volcanism. DIC thesis, Imperial College, London.

Mollel, G., Swisher, III C., Feigenson, M., Carr, M., 2008. Geochemical evolution of Ngorongoro Caldera, Northern Tanzania: Implications for crustmagma interaction. Earth and Planetary Science Letters, 271: 337-347.

Pickering, R., 1965. Ngorongoro. Tanzania Geological Survey Quarter Degree Sheet 53.

Pickering, R., 1994. Ngorongoro's Geological History. Ngorongoro Conservation Area Authority, Arusha, $52 \mathrm{pp}$.

Wood, C.P., 1968. A geochemical study of East African alkaline lavas and its relevance to the petrogenesis of nephelinites. $\mathrm{PhD}$ thesis, University of Leeds.

Żaba, J., 2005. The Kilimanjaro Volcano-geotouristic attraction in Africa. Geotourism, 1 (2): 3-12.

Żaba, J., Gaidzik, K., 2011a. The Ngorongoro Crater as the biggest geotouristic attraction of the Gregory Rift (N Tanzania, Africa) - geographical setting. Geotourism in preparation, 1-2 (24-25): 3-26.

Żaba, J., Gaidzik, K., 2011b. The Ngorongoro Crater as the biggest geotouristic attraction of the Gregory Rift (N Tanzania, Africa) - geotouristic valorization, touristic development and hazard. Geotourism, 1-2 (2425): 47-64. 